NOTES

\title{
REACHING BEYOND PERFORMANCE COMPENSATION IN ATTEMPTS TO OWN THE CORPORATE EXECUTIVE
}

\author{
JOSHUA A. KREINBERG
}

"Grab a man by his W-2 and his heart and mind will follow."

\section{INTRODUCTION}

It is axiomatic that proprietors seek to ensure that the efforts of all company employees redound to the benefit of the corporate enterprise. Nowhere during the past year, however, have misguided attempts to lead the heart and mind of the employee been more blatantly evident than in the securities industry. Celebrated firms such as Kidder Peabody \& Co. and Barings PLC have experienced financial disasters that were caused in no small part by their incentive compensation programs for high level officials.

In April 1994, a scandal rocked Kidder Peabody \& Co. (Kidder), an institution where compensation is largely based on performance and where many brokers generate $\$ 1$ million per year in commissions. ${ }^{2}$ Kidder fired Joseph Jett, a government-bond chief who reportedly created soine $\$ 350$ million in "fake profits" to cover for losses of $\$ 85$ million over a two-and-a-half-year period. ${ }^{3}$ Jett claimed his supervisors were aware of his trading practices and even had directed him in his actions. ${ }^{4} \mathrm{~A}$ Securities and Ex-

1. George Anders, The "Barbarians" in the Boardroom, HARv. Bus. Rev., JulyAug. 1992, at 79, 81 (quoting Donald Herdrich of Kohlberg Kravis Roberts \& Co.).

2. See Anita Raghavan, GE Moves to Quell Kidder Defections with Stock Bonuses, WALl ST. J., Oct. 11, 1994, at B16 (describing Kidder compensation); Michael Siconolfi, Kidder Expected to Slash Staff, Exit Some Lines, WALl ST. J., Oct. 4, 1994, at A3, A8 [hereinafter Siconolfi, Kidder Expected to Slash Staff]; Michael Siconolfi, To Spin Off Kidder Unit, GE Needs to Inject \$2.5 Billion, Report Says, Wall ST. J., Sept. 21, 1994, at C1, C25 [hereinafter Siconolfi, To Spin Off Kidder Unit]; Michael Siconolfi, Jett Fires Back, Says Kidder Refuses Data, WALL ST. J., Sept. 7, 1994, at C1, C17 [hereinafter Siconolfi, Jett Fires Back].

3. Siconolfi, To Spin Off Kidder Unit, supra note 2, at C1.

4. Id.; Siconolfi, Kidder Expected to Slash Staff, supra note 2, at A3. 
change Commission (SEC) report found "lax oversight" by Kidder executives but did not discuss why the company had allowed these executives to keep bonuses based on Jett's "phantom profits." The extent of knowledge and acceptance of Jett's activities remams unknown, but the scandal led to the departures of Kidder's chairman/CEO, its bond chief, its derivatives chief, and other senior executives. In addition, some of the departing officers as well as Kidder itself face SEC civil administrative charges for "failure to supervise"; Kidder continues to incur legal costs in its arbitration with Jett. ${ }^{6}$ The scandal contributed to a $\$ 475$ million loss in 1994,7 which in turn led to a "sweeping restructuring," including the layoff of 550 einployees, a reduction of assets, and a departure from certain business lines. ${ }^{8}$ Kidder's parent coinpany, General Electric, eventually sold the troubled securities firm.

In a tragically similar situation, Barings PLC (Barings), a 233year-old British banking institution recently collapsed and was taken over by Internationale Nederlanden Groep NV. ${ }^{9}$ One of the reasons for this collapse may have been Barings' incentive compensation plan, which traditionally led to the payment of $50 \%$ of gross earnings in the form of bonuses. ${ }^{10}$ Derivatives trader Nicholas Leeson, who stood to receive a bonus in 1994 of more than $\$ 500,000$, made considerable contributions to the profitability of Barings' Singapore operations until his high volume trading in Japanese futures and options resulted in more than $\$ 1$ billion of losses in late February 1995. ${ }^{11}$ Investigating authorities beheved that Leeson's superiors in London and Asia, many of whom would have received bonuses ranging from $\$ 1.4$ million to $\$ 2.6$ million, were aware of the risky transactions. ${ }^{12}$ Letters, internal audits,

5. Siconolfi, Jett Fires Back, supra note 2, at $\mathrm{C} 1, \mathrm{C} 17$.

6. Id. at C1; David E. Kalish, Legal Tussle Highlights Arbitration Weaknesses, DURHAM HeRALD-SuN, Oct. 16, 1994, at C4, C7; Micliael Siconolfi \& Laurie P. Colien, Kidder, Three Ex-Officials Likely to Face SEC Charges, WALL ST. J., Jan. 27, 1995, at A3.

7. See Siconolfi, To Spin Off Kidder Unit, supra note 2, at C1; Micliael Siconolfi, GE's Kidder Wins Round in Dispute with Joseph Jett, WALL ST. J., Oct. 7, 1994, at C17.

8. Miclsael Siconolfi \& Laura Jereski, Kidder Facelift Will Slash Its Wall Street Role, WALL ST. J., Oct. 7, 1994, at C1.

9. See Marcus W. Brauchli et al, Broken Bank: Barings PLC Officials May Have Been Aware of Trader's Position, WALl ST. J., Mar. 6, 1995, at A1, A7; Nicholas Bray, Barings Failed to React to Warnings, Preceding Collapse, Evidence Suggests, WALL ST. J., July 7, 1995, § B at 3A; Edith M. Lederer, Bank's Brass Faces Reports of Misdeeds, DURHAM HERALD-SUN, Mar. 6, 1995, at A1, A2.

10. Brauchli et al., supra note 9, at A7.

11. Id. at A1, A7.

12. Bray, supra note $9, \S \mathrm{B}$ at $3 \mathrm{~A}$; see also Nicholas Bray \& Glenn Whitney, 
meetings with regulators, and the sheer size of the twenty-eightyear-old's positions, which required that the London offices transfer more than $\$ 890$ million to cover the Singapore office's trading, indicate that others probably were aware of Leeson's trades. ${ }^{13}$

Such performance pay schemes in the securities field represent the typical response to public controversy in recent years over the compensation of high-level corporate executives. ${ }^{14}$ In 1991, the view that executive pay was "spiraling out of control" induced some members of Congress to attempt to restrict compensation for corporate officers. ${ }^{15}$ Similarly, after former President George Bush made a trade-related trip to Japan in 1992 accompanied by American executives whose compensation far exceeded that of their Japanese counterparts at the negotiating table, many Americans questioned the need to pay the country's top executives so dearly. ${ }^{16}$ Furthermore, populist attacks on the pay of business leaders rose to the level of a "pohtically correct" national pastime during the last presidential campaign. ${ }^{17}$

Executive compensation contimues to receive a ligh degree of coverage in the popular press. ${ }^{18}$ The pundits of corporate governance proclaim that grabbing a corporate executive's W-2 allows one to guide his heart and combat excesses at the top of the corporate ladder. ${ }^{19}$ They believe that performance pay represents the

Barings Collapse Tied to Wide Cast in Special Report, WALL ST. J., July 19, 1995, at A5.

13. Brauchli et al., supra note 9, at A1, A7.

14. E.g., DEREK BOK, THE COST OF TALENT 3 (1993) (citing surveys that show public support for increased taxation of such lighly paid individuals); John A. Byrne, The Flap Over Executive Pay, Bus. WK., May 6, 1991, at 90; Sarah A.B. Teslik, Tell Me Again Why the CEO Got a Bonus, PENSIONS \& INVESTMENTS, July 25, 1994, at 10 (disputing the notion that "a little larceny at the top will liave next-to-no effect on the bottom line").

15. Bill to Check Executive Pay, N.Y. TIMES, June 5, 1991, at D2 (statement by Sen. Carl Levin).

16. BoK, supra note 14 , at 95 .

17. Andrew R. Brownstein \& Morris J. Panner, Who Should Set CEO Pay? The Press? Congress? Shareholders?, HaRV. BuS. REV., May-June 1992, at 28, 28-29 (highlighting the issue that drew the attention of people such as then-Governor Bill Clinton and Vice President Dan Quayle).

18. See, e.g., The Wall Street Journal Reports-Executive Pay, Wall ST. J., Apr. 12, 1995, at R1-R16.

19. See, e.g., Susan L. Martin, The Executive Compensation Problem, 98 DICK. L. REv. 237, 237-39 (1994); Michael C. Jensen \& Kevin J. Murpliy, CEO Incentives-It's Not How Much You Pay, But How, HARv. Bus. Rev., May-June 1990, at 138, 139 (outlining the benefits of performance pay); see also Brownstein \& Panner, supra note 17, at 32 (criticizing proposed legislation that would limit deductibility of executive pay). 
sole acceptable solution and that other alleged remedies are "wrong headed."20 Some of the best human capital in busimess has been exhausted in efforts to artificially construct pay packages that create incentives for executives to maximize certain economic indicators. By drawing the attention of corporate management to economic and financial measurements, proponents of performance pay claim that executives will behave appropriately and that pay levels no longer will be a problem: If the whole corporation is doing well, high executive pay is acceptable. An executive's salary is considered to be just "peanuts" compared to the corresponding benefits to the company. ${ }^{21}$ Similarly, if the corporation is not performing well, performance pay's supporters allege that compensation should be of no concern because it will not reach high levels. Incentive pay offers a panacea purporting to solve all corporate governance ills. Seduced by the excitement of the performance-pay systein, regulatory bodies that act through the legislative and administrative inedia of tax law $^{22}$ and securities disclosure ${ }^{23}$ largely endorse the use of performance pay.

Notwithstanding these perceptions of the performance-pay pundits, the executive pay package is only the symptom of a much deeper, yet simpler, problem of corporate governance-the divergence of ownership and managenent interests. Management and ownership of the public company have become separated as corporate governance mechanisms have failed to create effective imcentives and rewards for management's contribution to long-term corporate wealth. Although pay-for-performance purports in theory to reakign management interests with those of ownership, the apphication falls far short of its objective and is not as effective as longterm equity ownership. With multiple inherent opporiunities for

20. Linda J. Barris, The Overcompensation Problem: A Collective Approach to Controlling Executive Pay, 68 IND. L.J. 59, 80 (1992) (quoting executive director of United Shareholders Association, who notes that other remedies do not "address the central issue, which is pay for performance. It's not how much [executives] get paid, it's how they get paid.").

21. Dana Wechsler, Would Adam Smith Pay Them So Much, Forbes, May 28, 1990, at 210, 210 (quoting millionaire investor Warren Buffett as saying "[y]ou'll never pay a really top-notch executive ... as nuch as they [sic] are worth. A million, $\$ 3$ million or $\$ 10$ million, it's still peanuts.").

22. I.R.C. $\S 162(\mathrm{~m})(1)$ (1995) (disallowing corporate tax deduction for nonperformance based executive compensation greater than $\$ 1$ million/year).

23. 17 C.F.R. § 229.402 (1994) (requiring inclusion of performance indicators in graphic and narrative form in proxy materials). 
abuse and manipulation, performance-based compensation packages often are detrimental to the long-term interests of the company; if taken to the extrene, these packages can even result in the financial failure of an entire organization as in the Kidder and Barings cases. The solution, however, lies not with any federally advocated mcentive-pay program but in the flexibility offered by the court system. The threat of effective judicial analysis of public corporation compensation decisions would provide the necessary impetus to remedy the current problem. Lowering the impenetrable legal walls that protect executive compensation decisions would allow courts to estabhish standards that are genuinely aligned with long-term proprietary interests.

This Note addresses the troublesome issues involved with the pay-for-performance systein, as well as executive compensation reform, and advocates that the courts focus on equity ownership as a solution. The symptom of high aggregate levels of executive compensation is described in Part I. Next, Part II canvasses the theories underlying the performance-system response to executive pay and outlines the shortcomings of the performance-pay regime: opportunity for nuanipulation in achievenent and in selection of targets; false sense of security for shareholders; distortion of incentives; and unnecessary coniplexity. Part III then describes the pay-for-performance endorsement by Congress and the SEC. The underlying corporate governance problenı of linking the concerns of proprietors and management by properly motivating and rewarding executives for contributing to the growth of long-term corporate wealth forms the basis of Part IV. Fimally, Part V proposes a system of flexible judicial analysis of compensation decisions in which the court system lowers the procedural defenses to provide both legitimate evaluation of the pay-setting environment and a comparison of compensation to the ideals of genuine ownership.

\section{THE SYMPTOM-PERCEPTIONS AND EVIDENCE OF ELEVATED EXECUTIVE COMPENSATION}

Even a cursory exammation of executive compensation in this country immediately reveals the syinpton: the behef of many Americans that the level of pay for top corporate officers is far too high. This view is reinforced by the supporting evidence of absolute pay in excess of that available to other professions and to foreign executives. Some survey results indicate that more than 
$75 \%$ of Americans may find executive compensation levels to be excessive. ${ }^{24}$ Descriptions of the compensation of chief executive officers (CEOs) and other top level corporate officials include "mind-numbing," "eye-popping," "breath-taking," "scandalous,"25 and "greed run amok."

A trend of pay escalation is evident from aggregate figures of executive compensation. ${ }^{27}$ Pay surveys place average CEO compensation in inajor American industrial companies at $\$ 3.56$ million for 1994 as compared to $\$ 3.28$ million in $1993 .{ }^{28}$ An analysis of the 1993 conipensation packages of the CEOs of the two hundred largest American corporations reveals that these corporate heads received an average of $\$ 4.1$ million. ${ }^{29}$ While the pay of individual CEOs niay have changed in 1993 and reached as high as $\$ 45.7$ million, ${ }^{30}$ the average value of pay packages has continued to climb. ${ }^{31}$ The package of executive pay usually consists of several components, including a fixed annual salary, a yearly cash bonus, and long-term incentive pay. ${ }^{32}$ Even in times of "corporate frugality" and economic difficulty, CEOs often benefit additionally from perquisites ranging from the relatively banal, such as use of company cars, boats, and jets, to the more unusual, such as the maintenance of personal flower beds and the right to purchase coinpany livestock. ${ }^{33}$ The long-term pay portion of the compensation

24. See BoK, supra note 14 , at 95 .

25. Id.

26. Barris, supra note 20, at 99 (statement by Robert Reich, Secretary of Labor).

27. The Boss's Pay, Wall ST. J., Apr. 12, 1995, at R13 (describing annual survey results that found "the highest total compensation" since the newspaper began printing such surveys in 1989).

28. CEOs Enjoy Fatter Bonuses This Year, BosTON GLOBE, Dec. 4, 1994, at A98 (reporting the results of a survey conducted by Pearl Meyer, a coinpensation consulting firm); Firm Says CEO Bonuses Up 37 Percent in 1994, DURHAM HERALD-SUn, Dec. 3, 1994, at D8. For the CEOs of the 350 largest U.S. companies, salary and bonus alone averaged $\$ 1,294,316$ in 1994 , a figure which is up $8.1 \%$ over 1993 figures. Joann $S$. Lublin, Raking It In, WALL ST. J., Apr. 12, 1995, at R1.

29. Brian Dumaine, $A$ Knockout Year, ForTUNE, July 25, 1994, at 94, 94. The Fortune survey used the Black-Scholes method to attempt to value stock option grants. Id. at 103.

30. Id. at 94 (payment for the services of Sanford I. Weill of Travelers, Inc.).

31. Id. (noting a $28 \%$ increase in average CEO compensation from the results of Fortune's 1992 study); Firm Says CEO Bonuses Up 37 Percent in 1994, supra note 28, at D8 (reporting that a consulting firm found a 37\% increase over 1993 compensation).

32. Graef S. Crystal, Selecting and Valuing Short- and Long-Term Compensation, in EXECUTIVE COMPENSATION: A STRATEgic GuIDE FOR THE 1990's 212, 212-13 (Fred K. Foulkes ed., 1991) [heremafter EXECUTIVE COMPENSATION].

33. In a Cost-Cutting Era, Many CEOs Enjoy Imperial Perks, WALL ST. J., Mar. 7, 
plan often is composed of stock options, which are restricted grants of the company's stock that may not be exercised for a period of ihree to five years, and stock appreciation rights, a type of cash payment which mirrors stock performance. ${ }^{34}$

Notwithstanding the fact that certain business analysts argue that levels of compensation do not pose a problem at all absent a company's poor rating agamst economic indicators, ${ }^{35}$ others claim that high pay has several detrimental effects. Morale problems may be created within corporations that pay top executives extremely well but do not show comparable generosity to employees down the corporate ladder. ${ }^{36}$ Recently, the president of a communications labor union local, whose members earn between $\$ 25,000$ and $\$ 35,000$ a year, summed up pay disparities by inquiring "[h]ow does anyone earn a million dollars? ... This is a very greedy company. ${ }^{37}$ Accentuated largely by disproportionate growth during the 1980 s when the pay of top executives rose by $212 \%$ whereas that of the factory worker increased by only $53 \%,{ }^{38}$ modern ratios of CEO to average worker pay represent a hefty inultiple ranging from 120 to $150 .{ }^{39}$ The stratification of employees into highly visible classes within a company can prove detrimental to overall corporate competitiveness, which depends largely on teamwork. ${ }^{40}$ Labor relations issues aside, large gaps in pay often sig-

1995 , at B1, B16.

34. IRA T. KAY, VALUE AT THE TOP: SOlutions to THE EXECuTtVe CoMPENSATION CRISIS 27-30 (1992). The deferred compensation of such long-term pay may create a misleading effect often present in the most shocking pay figures. One must bear in mind that some publicized figures include previously granted compensation that merely is realized by the executive during the current year and reflects a reward for service already rendered. One such example can be seen in the case of Disney CEO Michael Eisner, whose exercise of stock options worth $\$ 203$ million in 1993 continues to receive broad media coverage. E.g., Bernard Weinraub \& Geraldine Fabrikant, Disney Roiled After Dismissal, N.Y. TIMES, Sept. 23, 1994, at C1, C2. In 1993, Eisner earned the significantly sinaller sum of $\$ 760,000$. Dumaine, supra note 29 , at 102 .

35. E.g., Jensen \& Murphy, supra note 19, at 138 (noting that executive coinpensation only creates a problem when corporate leaders are paid "like bureaucrats," i.e., unrelated to performance).

36. BoK, supra note 14 , at 104-05; Teslik, supra note 14 , at 10.

37. Stephen Keating, Linking Performance, Pay Not Always Easy, DENVER POST, July 3, 1994, at G1.

38. Byrne, supra note 14 , at 90 .

39. GRAEF S. CRYstal, In SEARch of ExcEss 27 (1991).

40. Robert W. Keidel, Executive Rewards and Their Impact on Teamwork, in EXECUTIVE COMPENSATION, supra note 32, at 150, 152. 
nificantly disrupt firm productivity, even when they are only between management levels. ${ }^{41}$

Unnecessarily high executive compensation also can be a misallocation of resources and a dram on the economy. Funds used to compensate executives could be invested for other purposes such as research and development or the improvement of equipment and facilities. ${ }^{42}$ Reasonable compensation motivates an executive to perform the job, but "[o]nce the carrot is big enough to encourage total effort, a bigger carrot is wasteful." ${ }^{43}$ Such economic waste reduces the nation's ability to compete in foreign trade with countries that do not spend vast sums on their top executives. Industries such as automobile production and oil and gas distribution, in which the pay of American CEOs outstrips amounts awarded to Japanese and European corporate leaders by multiples of five to thirty, serve as prime examples of the competitive disadvantage of U.S. corporations. ${ }^{44}$ In Japan, the average CEO receives sixteen tines the salary of an industrial worker, while the ratio in Germany reaches twenty-one. ${ }^{45}$ Performance compensation plays only a "modest" role in German and Japanese pay. ${ }^{46}$ Generally using a compensation policy that is antithetical to the current American system, Japanese corporations seek to narrow the gap im einployee compensation in order to increase loyalty, cohesion, and productivity. ${ }^{47}$ Other arguments against high pay include the insulating effects of high pay on chief executives, ${ }^{48}$

41. CEO Pay: How Much Is Enough?, HARV. Bus. REv., July-Aug. 1992, at 130, 136 (stateinent by Jay W. Lorsch of Harvard Business School).

42. Carl T. Bogus, Excessive Executive Compensation and the Failure of the Corporate Democracy, 41 BUFF. L. REV. 1, 25 (1993).

43. Id. at 30 .

44. Id. at 26.

45. CRYSTAL, supra note 39, at 206-09.

46. Michael E. Porter, Capital Disadvantage: America's Failing Capital Investment System, HARV. BUS. REV., Sept.-Oct. 1992, at 65, 72; see also Raju Narisetti, Work Week: A Special News Report About Life on the Job-and Trends Taking Shape There, WALL ST. J., Nov. 1, 1994, at A1 (finding only $20 \%$ of Japanese-owned companies possess incentive-pay plans versus 50\% among U.S. coinpanies).

47. BoK, supra note 14 , at 105.

48. Jacques Delacroix \& Shahrokh M. Saudagaran, Munificent Compensations as Disincentives: The Case of American CEOs, 44 HUM. REL. 665 (1991) (finding no link between the "mythical" social function of performance and pay and arguing that current high levels of compensation can actually be counterproductive by protecting CEOs from the basic material consequences of bad performance). 
the needless creation of a self-perpetuating upper class ${ }^{49}$ and the broad societal incentives created among young people that impact the distribution of national talent. ${ }^{50}$

Notwithstanding the previously enumerated rationales, the central problem with high executive compensation is its relationship-or lack thereof-to the corporation's long-term interests. Analysis of compensation, by nature, must rest on a primarily subjective basis, ${ }^{51}$ that is, who is to say when absolute pay levels are excessive? Examining pay by considering the officer's direct impact on long-term wealth creation within his particular corporation would yield a better evaluation of coinpensation. While some analysts have attempted to measure the firm-specific relationship between CEO compensation and shareholder wealth, their work falls short of accounting for genume impact on the corporate enterprise as they opt for such proxies as short-term stock price. ${ }^{52} \mathrm{~A}$ complete evaluation of the appropriateness of the level of CEO compensation would demand a thorough analysis of the long-term relationship between each firm's chief executive and the company's value. In the absence of a firm-specific analysis, societal compensation levels offer limited information, and controlling such aggregate pay levels should not be an end unto itself.

In analyzing compensation levels, one must focus on two elements: aggregate pay levels and public opinion. The informational value of aggregate pay comes froin its role as a "barometer" for examining the operation of the corporate model..$^{53}$ Theoretically, the corporate structure itself should prevent compensation figures from rising to levels that are disproportionate to the executives' role im generating corporate wealth. When public opinion, however, generally views the compensation of CEOs as excessive, further analysis of compensation decisionmaking is necessary. Public perception may represent an understanding of the imbalance between pay and the long-term econormic value that execu-

49. See Bogus, supra note 42 , at $17-19$.

50. See BOK, supra note 14 , at $89,247-48,287$.

51. Bogus, supra note 42 , at 27 . The author suggests that a definition of "excessive" may be established, but such a measure depends on a factual determination of the situation that the sum in consideration surpasses the lowest level required to attract and motivate individuals while still awarding fair compensation. Id. at 28-29.

52. E.g., Jensen \& Murphy, supra note 19, at 150-53 (using a two-year information window).

53. Bogus, supra note 42 , at 80 . 
tives have added to the economy. Absolute numbers, when taken in conjunction with public opinion, should serve to flag one's attention. One would expect that in an ideal, fluid, global market economy, the pay of CEOs would be roughly similar to that of their counterparts abroad and most other American professionals, not including outliers such as professional athletes and entertainers. Thus, indications of high societal CEO compensation levels, a "baroineter [that] has continued to rise," symptom of a larger problem-a failure of corporate governance.

\section{PAY-FOR-PERFORMANCE-A FOCUS ON THE SYMPTOM}

Many proposed solutions focus inyopically on the visible symptom of high compensation levels. By devising absolute limits on the amounts that may be paid to corporate officers, some proposals empliasize this symptom to an extreme. One solution seeks to establish a uniform cap on the level of executive pay. ${ }^{55}$ Another proposed remedy resurrects a notion advocated by Plato-the creation of a fixed pay-ratio between the highest and lowest paid employees within the corporation. ${ }^{56}$ Pay-ratio proposals liave varied on the exact ratio that should exist with suggested inultiples ranging from five to twenty-five times. ${ }^{57}$ The performance-based system, however, seems to liave triumphed.

Performance pay is not a new idea. Julius Caesar awarded his soldiers a percentage of the spoils from successful Roman military endeavors. ${ }^{58}$ By 1932 , even Babe Ruth recognized the role of performance in compensation when explaining why he earned $\$ 5,000$ more than President Herbert Hoover, saying: "I had a better year than he did." 59 Similarly, the wide use of performance pay in cor-

54. Id.

55. BoK, supra note 14, at 117 (noting several problems involved with the Congressional establishment of a mandatory ceiling including issues of valuation and the distortion of the "flow of talent" into occupations).

56. CRYSTAL, supra note 39 , at 23-24.

57. E.g., id. at 24. In addition to Plato, the following individuals and entities have also proposed or used certain fixed ratios in compensation: (1) J.P. Morgan, Id.; (2) business guru Peter Drucker, Peter F. Drucker, Is Executive Pay Excessive?, WALL ST. J., May 23, 1977, at 20; (3) Ben Cohen of Ben \& Jerry's Ice Cream, Keating, supra note 37, at G1; and (4) Minnesota Congressman Martin Sabo, Incoine Disparities Act, H.R. 3056, 102d Cong., 1st Sess. (1991).

58. David J. McLaughlin, The Rise of a Strategic Approach to Executive Compensation, in EXECUTIVE COMPENSATION, supra note 32, at 5, 6.

59. CRYSTAL, supra note 39 , at 26 . 
porate America dates at least as far back as World War I, when executives began to receive large portions of their compensation in the form of bonuses. ${ }^{60}$ Shortly thereafter, stock options arose as a popular form of executive pay during World War II. ${ }^{61}$

Whether the employee is a Roman centurion annihilating Carthaginians or a door-to-door vendor pushing encyclopedias on the Joneses, the same notion exists: Pay can create imcentives to direct and dictate the behavior of individuals. Corporate analysts frequently note the "strategic" importance of the role that compensation assumes for the "success of a busmess venture." ${ }^{.62}$ Compensation plans possess the "potential to motivate executives and focus their energies on behavior that directly supports or fulfills organizational goals." ${ }^{\prime 63}$ Performance-pay supporters beheve that if one desires certam behavior, one can offer rewards specifically tailored to generate the achievement of that behavior.

With some $95 \%$ of all large corporations favoring the use of bonuses or inerit pay, performance compensation is a inodel that is "rarely questioned" and almost blindly accepted in "business circles" today. ${ }^{64}$ The general notion of linking pay to performance has found a following in several industries as varied as fund management, ${ }^{65}$ professional athletics, ${ }^{66}$ custodial services, ${ }^{67}$ and education. ${ }^{68}$ The populist ideals of social justice where an individual's rewards ostensibly depend on his personal contribution to the benefit of the collective entity probably have contributed to the near total lack of resistance to this notion's application in the executive coinpensation context. ${ }^{69}$

60. BoK, supra note 14 , at $39-40$.

61. Id. at 40 .

62. McLaughlin, supra note 58, at 6, 22; see, e.g., Jan P. Muczyk, The Strategic Role of Compensation, 11 HuM. ResourCE PlAN. 225 (1988); Ray Stata \& Modesto A. Maidique, Bonus System for Balanced Strategy, HARv. BUS. REV., Nov.-Dec. 1980, at 156.

63. Bruce Overton, How to Organize, Staff, and Develop Skills Within the Executive Compensation Function, in EXECUTIVE COMPENSATION, supra note 32, at 325, 325.

64. BOK, supra note 14 , at 106.

65. Jaclyn Fierman, The Coming Investor Revolt, ForTUNE, Oct. 31, 1994, at 66, 67.

66. It's Official: 49ers To Be in Prime Time, N.Y. TIMES, Sep. 16, 1994, at B14.

67. Steven L. Myers, Giuliani Unveils New Contract With Custodians of City Schools, N.Y. TIMES, Oct. 15, 1994, at A1, A22.

68. Joseph Berger, For Mercer College Teachers: Recruit a Student, Get a Raise, N.Y. TIMES, June 10, 1995, at 21-24.

69. See BOK, supra note 14, at 106 (describing the "results-oriented ethos" of the moderu corporation as strongly supporting performance pay). 
Performance packages assume the incentive impact of pay and divide its motivating capacity into artificially constructed elements. Pay packages attempt to micromanage the decisionmaking processes of executives by forcing them to focus on achieving certam performance goals. An executive's pay is distributed between specific short-term goals and a few long-term incentives. ${ }^{70}$ The desired performance can imvolve a multitude of criteria-whatever the directors and their pay consultants select as the proper carrot to wave for the executive's performance. Examples include achieving certain target levels of return on investment, return on equity, or volume sales figures. ${ }^{71}$ No consensus, however, exists among busmess analysts over the specific measures to be targeted. ${ }^{72}$ Theoretically, the constructed packages should leave executives with strong incentives to engage in the desired performance. If performance pay were to succeed in encouraging behavior and the objectives had been appropriately crafted, no one would need to worry about resulting pay levels because the corporation, its shareholders, and the economy on the whole would have enjoyed the benefit of increased corporate performance.

If the individual who is targeted values the rewards in a manner similar to the employer, he will strive to attain those rewards. The behavior, however, must be within the particular person's own perceived capacity to control. As expectancy theory dictates, if an individual beheves he can achieve rewards and values them appropriately, he will strive to achieve those goals. ${ }^{73}$ Naturally, the goals must actually be attainable or the individual will become frustrated and no longer will be motivated to act. ${ }^{74}$

70. Crystal, supra note 32, at 212-13 (proposing appropriate breakdown between short-term and long-term measures depends upon the individual company's business cycle); e.g., IBM, PROXY STATEMENT 9-10 (1994).

71. Charles T. Horngren et al, Cost AcCounting: A Managerial EmpHasis 892-95, 906 (1994).

72. E.g., Seymour Burchman, Choosing Appropriate Performance Measures, in EXECUTIVE COMPENSATION, supra note 32, at 189, 194-96 (discussing shortcomings of the use of accounting measures); KAY, supra note 34, at 189 (disapproving of the use of accounting measures); Michael E. Ragsdale, Executive Compensation: Will the New SEC Disclosure Rules Control "Excessive" Pay at the Top, 61 UMKC L. REV. 537, 564 (1993) (citing research supporting an accounting basis for compensation).

73. See, e.g., Edward E. Lawler III, The Organizational Impact of Executive Compensation, in EXECUTIVE COMPENSATION, supra note 32, at 129, 131; David J. McLaughlin, Does Compensation Motivate Executives?, in EXECUTIVE COMPENSATION, supra note 32, at $59,63,68$.

74. BoK, supra note 14 , at 245 . 
Even when the corporation's goals are attainable and the model otherwise has been effectively implemented, performance pay in American society falls short of its purported objectives. In attempts to find a panacea for the symptom of the perception of high CEO compensation, analysts have rushed to endorse the performance-pay system even though the theory that forms the basis for performance pay may itself be flawed. Although economists generally accept the notion that money represents a sufficient motivation, many psychologists and management theorists question the effectiveness of monetary prizes as the sole incentive for one's actions. ${ }^{75}$ Other factors such as interest in work, recognition, achievement, and colleagne opimion may influence individuals more than "crass material rewards." ing view" of a self-serving management. ${ }^{77}$ Pay inay have only a marginal impact on top corporate executives, the vast majority of whom already enjoy considerable wealth. ${ }^{78}$ Sone studies even indicate that pay $\mathrm{m}$ excess of a certain point can result in diminished inarginal returns and even lower performance levels. ${ }^{79}$

Performance pay's susceptibility to manipulation, rehance on unicromanageinent, and distortion of incentives actually serve to harm the corporation. The purported performance regime may not reflect genuine performance at all if it selects inadequate indicators. While appearing to be based on performance, certain pay packages may be constructed utilizing "various pay gimmicks," which actually result in guaranteed levels of compensation largely independent of manageinent performance and benefit to the company. ${ }^{80}$ Poor performance can persist in incentive pay systems,

75. Id. at 22-23 (citing examples such as Chester Barnard, author of that "classic of management texts, The Function of the Executive," and W. Edwards Deming, "father of 'total quality management"').

76. Id.; see, e.g., Ana Azevado \& Leonard H. Clusmir, Motivation Needs of Sampled Fortune-500 CEOs: Relations to Organization Outcomes, 75 PERCEPTUAL \& MOTOR SkILIS 595 (1992) (finding a correlation between achievement and growth in corporate sales and power and growth in profits); Bernadette M. Ruf \& Leonard H. Chusmir, Dimensions of Success and Motivation Needs Among Managers, 125 J. PsYCHOL. 631 (1992) (noting that power and achievement correlate with personal fulfillment and other factors in addition to status and wealth).

77. BoK, supra note 14 , at $109,244$.

78. Id.

79. Letters to the Editor: CEO Pay Just Greed?, HARV. BUS. REV., Sep.-Oct. 1992, at 193, 194 (letter from Clyde P. Otivier).

80. E.g., CRYSTAL, supra note 39, at 84 (describing method by which Steven J. Ross, the former CEO of Warner Comununications, relied on "pay gimmicks" to ensure his 
such as the now infamous situation of IBM, in which the coinpany's incentive pay system allowed it to offer former CEO John Akers large rewards despite "one of the worst corporate performances in history."

One of the worst forms of guaranteed pay in otherwise performance-driven coinpensation packages is the revaluation of options by directors. If the market price of a company's stock has fallen or has failed to rise sufficiently, an executive's option package may not represent any immediately realizable value. When directors feel that an executive has been underpaid, they may elect to revalue his compensation by lowering the exercise price of previously granted options. Revaluation allows directors to remove effectively the downside risk of performance pay while maintaining some semblance of a competitive compensation. The practice of option repricing has been analogized to an unusual high jump event in which the bar one must clear is continuously lowered to facilitate its clearance..$^{82}$ The ostensible justification for the lowering of pay standards is that an executive has been harmed unfairly by adverse market conditions.

In addition to revaluation, setting initially low perfornnance thresholds that are certam to be achieved causes no trouble at all for boards wishing to secure compensation for their executives. Directors also can grant multiple interlocking performance measures to ensure that at least one of thein will be fulfilled. ${ }^{83}$ This practice guarantees executives a certam pay level while constructing the package out of individually risky performance-dependent itens much in the same way as an investment portfolio. Through such mechamisms, companies may "pile one form of executive compensation on top of another," continuing to raise the level of topmanagement pay independent of corporate performance. ${ }^{84}$

compensation level).

81. E.g., Teslik, supra note 14, at 10 (pointing also to examples at General Electric, Westinghouse, Coca-Cola, and Time-Warner); IBM, supra note 70 , at 9,11 (outlining a company philosophy of "pay-at-risk," rewarding annual and long-term financial performance and simultaneously paying the departing Akers over $\$ 3$ million, including an "incentive [bonus] payment" and an additional payment ostensibly in "recogrition of his 33 years of service to the Company"). A more mundane example is presented by the 1994 earnings of George Fisher, the CEO of Eastman Kodak Co., who collected a $\$ 1.7$ million bonus even though Kodak's earnings fell below its target. Lublim, supra note 28, at R4.

82. CRYSTAL, supra note 39 , at 107. 18.

83. Geoffrey Colvin, How to Avoid the CEO Pay Cap, FORTUNE, Mar. 20, 1995, at

84. CRYSTAL, supra note 39 , at 107-08 (noting the example of CEO Peter Grace of 
Some indicators also may lend themselves to direct tampering by the executive after the committee develops the package. ${ }^{85} \mathrm{Al}-$ though any individual may experience frustration if he finds himself unable to influence compensation indicators despite his personal efforts to do so, a situation of excessive control over indicators can result in abuses. ${ }^{86}$ For instance, focusing pay on financial measures such as return on equity allows management to increase its personal compensation by subtly manipulating discretionary responsibilities such as advancmg the sale date of certain assets or electing a source of project finance. Executives can also "sweeten" financial reports through such devices as the sale-and-lease-back arrangements employed by Agee at Morrison Knudsen ${ }^{87}$ or the advance booking of sales used by executives at Kurzweil Applied Intelligence ${ }^{88}$ Similarly, extreme short-run stock price can be mampulated through the disclosure or delay of disclosure of certain bits of information that do not rise to the level of materiality necessary for securities law violations. ${ }^{89}$ Since accounting measures often provide hittle genuine link to positive long-term corporate performance, removing stock-based compensation with its direct link to shareholder return and relying on "accounting-based, long-term cash coinpensation plans" would lead to a "replay of the 1970s, when the tracking of executive compensation and shareholder return was more coincidence than compensation." 90

Since performance-pay provides an appealing justification for a high level of coinpensation, shareholders niay feel a false sense of security and not properly investigate pay procedures, even though positive performance indicators nıay create a mere façade of contribution to the long-term interests of the company. Even option revaluation can be defended to shareholders as firms rationalize the repricing of executive options with strike prices above the

the poorly performing W.R. Grace).

85. See Dean Faust, The SEC's CEO-Pay Plan: No Panacea: Studies Suggest Linking

Pay to Performance Actually Hurts Performance, Bus. WK., July 6, 1992, at 37.

86. BoK, supra note 14 , at 245.

87. Joan E. Rigdon \& Joann S. Lublin, Call to Duty: Why Morrison Board Fired Agee, WALL ST. J., Feb. 13, 1995, at B1, B4.

88. Steve Stecklow, Three Kurzweil Officials Quit, Fourth Fired Afier Sales Inquiry; Stock Plunges, WALL ST. J., May 24, 1994, at B7.

89. See Cede \& Co. v. Technicolor Inc., 634 A.2d 345, 363-64 (Del. 1993).

90. Theodore R. Buyniski, The Past, Present, and Possible Future Role of Executive Compensation Plans, in EXECUTIVE COMPENSATION, supra note 32, at .290, 309. 
market, believing such out-of-the-money options to be of no positive motivational use and a dangerous imcentive for executives. ${ }^{91}$

More than a justification for poor performance, performancebased systems can distort imcentives and actually encourage harmful behavior. If an individual's pay hinges upon the attainment of a certain economic indicator, he may be willing to allow questionable practices to occur in order to reach the indicator. ${ }^{92}$ Inherent motivational problems plague performance-pay applications:

[E]fforts to link pay to performance cause professionals to focus on making more money instead of doing the best possible job. Those who admimister compensation do their best to make the two goals coincide, but this is rarely possible for the complex work that most executives and professionals perform. In one way or another, opportunities arise to boost one's income at the expense of the organization. ${ }^{93}$

Although criminal and civil law usually provide a check on extreme behavior, sufficient freedom exists to engage in marginally ethical activity. ${ }^{94}$ A compensation plan that encourages such abuses by einployees at any level within the company can severely damage the company's reputation and goodwill. The experience of Sears Roebuck \& Co.'s automotive service department exemplifies the potentially disastrous results that can accompany performance pay. Productivity imcentives and sales quotas employed at Sears led to a corporate environment of "pressure, pressure, pressure" as well as poor quahty and a legal settlement of $\$ 60$ milhon. ${ }^{95}$ The company eventually issued a full page apology in the Wall Street Journal, stating, "[w]e have concluded that our incentive compensation and goal-setting program inadvertently created an environment in which mistakes have occurred. We are moving quickly and aggressively to eliminate that environment. ${ }^{396}$ When the pay of

91. See CRYSTAL, supra note 39 , at 71 .

92. BoK, supra note 14, at 245 (noting frequent failure of performance-based system to set rewards "large enough to motivate effectively but not so large as to tempt people to resort to improper or even illegal behavior to qualify").

93. Id. at 246 .

94. See Lynn Sharp Paime, Managing for Organizational Integrity, HARV. BUS. REV., Mar.-Apr. 1994, at 106, 108-10 (arguing for need of "organizational ethics" to prevent poor decisionmaking which led to multimillion dollar losses for several companies).

95. Id. at $107-08$.

96. HORNGREN ET AL, supra note 71, at 905 (quoting An Open Letter to Sears Customers, WALL ST. J., June 25, 1992, at C11). 
the highest executives hinge on performance-based compensation measures, the dangers to the system are exacerbated as top management may allow hazardous behavior to filter down the entire corporate ladder. The financial debacles at Kidder and Barings serve as testament to the risks of high-level performance pay as the incentive distortions involved proved to be much greater than any positive returns from performance ineasures.

Moreover, the incentive systems often improperly lead to pay that focuses on short-term indicators. ${ }^{97}$ Executives, tied to the short-term interests of the corporation, may engage in behavior harmful to long-term corporate needs. ${ }^{98}$ Business consultants claim that neglecting such short-run incentives can lead a corporation into cash-flow trouble as managers risk bankruptcy by planning only for the long-run. ${ }^{99}$ However, bankruptcy would be unlikely in a genuine long-term proprietary situation because a firm failure would destroy the financial livehilood of an executive whose fortunes are linked to the firm. Unlike diversified shareholders, bankruptcy poses a real threat to the professional reputations and careers of executives. Nevertheless, performance pay places such an emphasis on short-term indicators that one may wonder who is attending to the company's long-term interests in this micromanaged incentive compensation system. Shareholders will do little to alleviate the near-sighted focus of the pay packages of American executives smce they hold stock on average less than two years. ${ }^{100}$ In addition, natural tendencies already exist for compensation committees to "tacitly" reinforce short-term goals by their continued rehance on tools sucl as peer group surveys to construct pay packages. ${ }^{101}$ Long-term equity compensation may

97. E.g., Sue Ellen Dodell, Experience Under the New Rules: Investment Community Perspective, in 350 EXECUTIVE COMPENSATION REPORTING 1993: LIVING WITH THE NEW RULES 223, 230 (Stanley Keller \& John F. Olson, eds., 1993) [hereinafter ExECUTIVE COMPENSATION REPORTING] (noting complaints of the New York City Comptroller to the SEC chair that disclosures including the performance graph would force companies to focus on current returns rather than goals such as research aud development and longterm growth).

98. E.g., BoK, supra uote 14, at 112-13 (outlining risks of inventory depletion and lack of research and developmeut expenditures); see also Molly Baker, I Feel Your Pain?, WALL ST. J., Apr. 12, 1995, at R6 (noting temptations to engage in "misguided restructurings, layoffs, and divestitures").

99. See Crystal, supra note 32, at 212.

100. Porter, supra note 46 , at 68 (pointing to problems caused by short investment horizons in country where the average stock holding period fell froin seven years in 1960 to two years today).

101. Walter J. Salmon, Crisis Prevention: How to Gear Up Your Board, Harv. BuS. 
provide a workable solution. When long-term compensation is used, however, it often lacks any down-side risk. ${ }^{102}$

The performance system is unnecessarily complex. The compensation consulting industry has arisen over the past couple of decades almost exclusively to service the needs of such micromanaged imcentive compensation plans. ${ }^{103}$ After establishing the desired goals, consultants create coinplex formulas and select esoteric economic indicators to construct artificially a corporate governance instrument that motivates executives to perform their jobs as if their interests were aligned with those of ownership. ${ }^{104}$ In the absence of such time-consuming mental exercises, extensive economic resources and human capital could be saved and allocated to other more pressing business issues. Federal efforts to mandate such a performance compensation system have primarily served only to make "mighty big winners" out of the "high-priced comp consultants." 105 Nevertheless, a vocal contingent of busmess pundits, administration officials, legislators, and other institutional representatives continue to praise incentive compensation for executives, thereby neglecting the underlying problem of corporate governance and performance pay's contribution to the problem.

\section{REgulatory Role-ENdorsement of PERFormance}

The regulatory bodies have succumbed to the performance-pay wave in electing to focus on the symptom rather than the problem. Congress and the SEC advocate a performance-pay system for executives. President Bill Clinton made controlling executive compensation excesses an issue in his 1992 campaign. ${ }^{106}$ The regulators seemed to follow through on the implementation of this campaign promise by acting through tax law and proxy rules to control behavior within America's business community. Even if these regulatory bodies possess the authority to establish potential corporate governance rules, ${ }^{107}$ general concern still can arise as to the

\footnotetext{
REV., Jan.-Feb. 1993, at 68, 70.

102. See supra text accompanying notes 80-84.

103. CRYSTAL, supra note 39 , at $215-16$.

104. The consultants' construction of the package will be prone to the upward bias due to the frequent use of comparison data. Id. at $43-44$.

105. Colvin, supra note 83 , at 18 .

106. E.g., Martin, supra note 19, at 237.

107. The executive compensation regulations could constitute an intrusion into the prohibited realm of corporate governance. See Cort v. Ash, 422 U.S. 66, 84 (1975); Busi-
} 
soundness of an executive compensation policy developed by bureaucrats rather than business leaders.

\section{A. Congress}

Congressional legislators have considered several measures to deal with the executive compensation issue. ${ }^{108}$ Absolute caps and ratio systems were rejected in favor of a pay-for-performance approach. As part of the Omnibus Revenue Reconciliation Act of $1993,{ }^{109}$ Congress amended the business expense section of the tax code so that annual compensation paid to the CEO and the four other highest paid officers in excess of $\$ 1$ million is no longer deductible as an "ordinary and necessary" business expenditure. ${ }^{110}$ Congress, however, allowed an exception for incentivebased compensation. The cap does not include employee remuneration that is payable "on a commission basis solely on account of mcome generated" by the individual's performance. ${ }^{111}$ Additionally, if compensation hinging on the "attainment of one or more performance goals" meets certain procedural requirements, it may qualify for the full deduction from income. ${ }^{112}$

The exception provides an obvious incentive for corporations to structure pay systems based on purported performance indicators. According to one recent survey of public firms, $86 \%$ feel that the tax law affects them, and $69 \%$ plan on trying to keep the compensation expense deduction. ${ }^{113}$ Corporations choosing to ignore

ness Roundtable v. SEC, 905 F.2d 406 (D.C. Cir. 1990). The SEC actions have been described as attempts at "disciplime" rather than "disclosure." Joseph Hinsey IV, The SEC Fix on Executive Pay: Improved Disclosure or Intrusion?, HARV. BUS. REV., Jan.Feb. 1993, at 77.

108. See, e.g., Tax Simplification Act of 1993, H.R. 13, 103d Cong., 1st Sess. (1993); Accountability Act, S. 2329, 102d Cong., 2d Sess. (1992); S. 2330, 102d Cong., 2d Sess. (1992); Income Disparities Act, H.R. 3056, 102d Cong., 1st Sess. (1991) (disallowing tax deduction for executive pay excceding 25 times that of the lowest paid employee); see also Corporate Pay Responsibility Act, H.R. 2522, 102d Cong., 1st Sess. (1991); S. 1198, 102d Cong., 1st Sess. (1991) (mandating disclosure regarding director and top management compensation).

109. Pub. L. No. 103-66, § 13211, 107 Stat. 312, 469-71 (1993). The Act redesignated subsection (m) as subsection (n) and inserted new subsection (m) to I.R.C. $\S 162$ (1995).

110. I.R.C. §§ 162(a), 162(m)(1), (3) (1995).

111. Id. § $162(\mathrm{~m})(4)(\mathrm{B})$.

112. Id. $\S 162(\mathrm{~m})(4)(\mathrm{C})$. Procedure requires that (1) a compensation committee comprised only of "outside directors" establish the goals; (2) shareholders approve thein; and (3) the compensation committee ccrtifies that goals were met. Id.

113. Gerald A. Achstatter, Will $\$ 1$ Million Tax Cap Hurt Executive Pay?, Investor's 
the performance-based option lose their tax deduction and must explain in disclosures to their shareholders why the corporation's tax bill was higher than necessary. Although corporations may still choose to avoid the performance system, they are penalized for doing so, and shareholder attention will focus on this decision. ${ }^{114}$ If hitigation results from compensation decisions, a court's attention could also be drawn to the tax treatment of the sum awarded. ${ }^{115}$ The net effect on executive compensation may be merely to force boards to engage erroneously in "bureaucratic" decisionmaking in which they closely follow the congressionally approved method of compensation. ${ }^{116}$

\section{B. Securities \& Exchange Commission}

The SEC has formulated a multifaceted approach to executive compensation that uses the proxy as a tool to focus on shareholder proposals, communications, and the corporation's compensation disclosures. Through certain no-action letters ${ }^{117}$ and rule changes, ${ }^{118}$ the Commission has sought to incorporate shareholders more fully into the compensation process and to facilitate imtershareholder communications im general. ${ }^{119}$ The changes, however,

Bus. DAILY, Aug. 22, 1994, at A4.

114. Tom Herman, Tax Report: Executive Pay Plans Get a Fresh Look Because of a Tax-Law Change, WALL ST. J., June 7, 1995, at A1.

115. See Wilderman v. Wilderman, 315 A.2d 610, 615 (Del. Ch. 1974) (listing as a factor in the determination of the reasonableness of remuneration whether a deduction would be permitted for the full amount of the executive's salary).

116. See Roberta S. Karmel, Securities Regulation: Focus on Executive Compensation, N.Y. L.J., Apr. 21, 1994, at 3, 7.

117. On February 13,1992, the SEC issued multiple no-action letters finding shareholder proposals related to executive compensation nonexcludable. E.g., Bell Atlantic Corp., SEC No-Action Letter, [1991-92 Transfer Binder] Fed. Sec. L. Rep. (CCH) II 76,110 (Feb. 13, 1992) (attempting to abolish short-term incentive plans for senior managenient); Chrysler Corp., SEC No-Action Letter, [1991-92 Transfer Binder] Fed. Sec. L. Rep. (CCH) II 76,103 (Feb. 13, 1992) (seeking to limit senior executive coinpensation with a policy of permanent strike price for future stock options); Baltimore Gas \& Elec., SEC No-Action Letter, [1991-92 Transfer Binder] Fed. Sec. L. Rep. (CCH) II 76,101 (Feb. 13, 1992) (seeking to cap executive pay at 20 times that of the employee average). In March, the Commission followed its earlier actions by releasing a no-action letter mandating the inclusion of a request for the company to create a compensation committee. Reebok Int'l Ltd., SEC No-Action Letter, [1991-92 Transfer Binder] Fed. Sec. L. Rep. (CCH) I 76,131 (Mar. 16, 1992).

118. Regulation of Communication Among Shareholders, 57 Fed. Reg. 48,276 (1992) (codified at 17 C.F.R. \& 240.14a-2(b)).

119. E.g., Executive Compensatiou Disclosure, 57 Fed. Reg. 48,126, 48,138 (1992) (to 
have had hitle impact on the executive compensation decisionmaking process. Few institutional imvestors take advantage of their powers, and those that do usually are unsuccessful in their efforts to exert their influence fully. ${ }^{120}$ Institutional investors focus their efforts largely on Fortune 500 companies and ignore other firms. ${ }^{121}$ In addition, they often side with management on governance issues. ${ }^{122}$ The Wall Street Rule-the rule that investors may "vote with their feet" by selling their shares when they disprove of corporate policy-and the costs/benefit analysis required of mstitutional mvestors combine to ensure that investors will not act unless the harmful effects of the compensation policy are clearly manifest. ${ }^{123}$ The greater freedom of communication even may create extra headaches for companies forced to include frivolous pay-related proposals offered by small investors. ${ }^{124}$ In fact, the ideal compensation decisionmaking process would not require the complications of proactive shareholder votes and actions if a legitimate threat of post-decision shareholder review existed.

In October 1992, the SEC also revised the executive compensation disclosure requirenents in proxy materials. ${ }^{125}$ Adding to the original requirements in 1993 , the Commission mandated that the committee outline its attempts to achieve the deductions delimeated .under section 162(m) of the Internal Revenue Code. ${ }^{126}$ Pursuant to the goal articulated by the Commission, ${ }^{127}$ the disclosure sheds more hight on the compensation decision process. The additional requirements, especially those involving disclosure of revalued options ${ }^{128}$ and interlocking compensation committee mem-

be codified at 17 C.F.R. $\S \S 228,229,240,249$ ).

120. Martin, supra note 19 , at 240.

121. Id.

122. David E. Bergdahl, Shareholder Proposals and Executive Pay: the SEC Makes a Fundamental Policy Change, 17 S. ILL. U. L.J. 117, 130 (1992).

123. See infra text accompanying notes 173-87.

124. Bergdahl, supra note 122 , at 117,134 (describing example of small shareholder nuisance proposals faced by Bell Atlantic Corp.).

125. Executive Compensation Disclosure, 57 Fed. Reg. 48,126 (1992) (to be codified at 17 C.F.R. $\S \S 228,229,240,249)$.

126. Executive Compensation Disclosure; Securityholder Lists and Mailing Requests Exchange Act Release No. 33,229, Securities Act Release No. 7032, [1993 Transfer Binder] Fed. Sec. L. Rep (CCH) II 85,259, at 84,812 (Nov. 22, 1993).

127. See SEC Adopts Proxy Reform Package Afier Long Study and Intense Debate, Sec. L. Daily (BNA) (Oct. 16, 1992); 57 Fed. Reg. 48,126.

128. 17 C.F.R. § 229.402(c) (1994) (Instructions to Item 402(c)). 
bership, ${ }^{129}$ may force boards and their compensation committees to further develop their executive compensation decisions. With the new graphical and tabular representations and comparisons against industry and market averages, ${ }^{130}$ however, the changes also focus shareholder attention solely on performancebased measures of pay. ${ }^{131}$ Compensation committee members likewise will be drawn to the easily identifiable performance measures as the center of their own analysis. Now that proxy materials publicly link committee members' names with their decisions, ${ }^{132}$ they have extra imcentive to concentrate on the same factors that will be the principal elements of shareholder analysis. Although the SEC expressly stated that no additional hability will ensue under Sections 14(a) \& 18 of the Security Exchange Act of $1934{ }^{133}$ hability under Section $10(\mathrm{~b})$ and Rule $10 \mathrm{~b}-5$ may still concern committee members. ${ }^{134}$ In addition to "saddl[img boards] with very complex regulation and disclosure of executive compensation," the rule changes may create a fear of hability that would drive companies to motivate executives through the rigid government-advocated performance system. ${ }^{135}$ If the package appears to be performance-based, shareholders may trust that benefits will accrue to them and become lax im any supervisory role they otherwise would have undertaken.

\section{CORPORATE GOVERNANCE-A LOOK BEYOND THE SYMPTOM TO THE PROBLEM}

In a corporation, unlike in a sole proprietorship or even a partnership, the link between ownership and control is severed. ${ }^{136}$

129. Id. § 229.402(j).

130. E.g., id. $\$ 229.402$ (b), (l). A summary compensation table requires that a company display an itemization of the remuneration paid to the CEO and the four highest paid company officers. This figure could be displayed previously as an aggregate number. Id. § 229.402(b). The information must contain a performance graph that compares in limear form the company to an accepted index. Id. § $229.402(l)$.

131. Ragsdale, supra note 72, at 564; Patrick J. Straka, Executive Compensation Disclosure: The SEC's Attempt to Facilitate Market Forces, 72 NEB. L. REv. 803, 834-35.

132. 17 C.F.R. \& 229.402(k)(3) (1994).

133. Id. \& 229.402(a)(9). The SEC's issuing remarks noted: "If shareholders are not satisfied with the decisions reflected in the report, the proper response is the ballot, not resort to the courts to challenge the disclosure." Executive Compensation Disclosure, 57 Fed. Reg. 48,126, 48,138 (1992) (to be codified at 17 C.F.R. $\S \S 228,229,240,249$ ).

134. Straka, supra note 131 , at $831-32$.

135. Karmel, supra note 116 , at 3.

136. Wesley R. Liebtag, Compensating Executives: The Development of Responsible 
While the corporation's equity is owned by the shareholders, managers act as agents for the shareholders and make decisions governing the company's daily operations. Obviously, the views and desires of the principal and the agent may differ. Compensation and control of management behavior become simple, yet pervasive, difficulties inherent in this agency relationship. ${ }^{137}$ Pay-for-performance compensation packages move pay reform, at least in theory, in the correct direction by attempting to realign the interests of management and shareholders through the tailoring of management's compensation to specific corporate measures. ${ }^{138}$ The lack of ownership by corporate management, however, is an imperfection that remains inadequately addressed in the corporate structure, the market, and the judicial system. The most effective answer to the agency problem may be simply ownership itself. A nontransferable long-term equity ownership in the corporate enterprise would prove beneficial to the operation of American businesses because shareholder and management interests would be inextricably connected. ${ }^{139}$ Ownership "prevents top corporate executives from walking away from a losing game for shareholders without losing something theinselves." 140 The current lack of management equity holdings leads to poor internal decisionmaking in the corporation. ${ }^{141}$ A significant proprietary interest would ensure that any rise or fall in long-term corporate fortunes would be felt by managers.

Artificially constructed pay substitutes for ownership, however, can distort incentives and become subject to manipulation theinselves. High pay from compensation packages does not necessarily

Management, in EXECUTTVE COMPENSATION, supra note 32, at 27, 27.

137. Richard A. Lambert \& David F. Larcker, Executive Compensation, Corporate Decision Making, and Shareholder Wealth: A Review of the Evidence, in EXECUTIVE Compensation, supra note 32, at 98, 100-01; Charles M. Yablon, Overcompensating: The Corporate Lawyer and Executive Pay, 92 CoLuM. L. REv. 1867, 1875 n.20 (1992).

138. E.g., Jensen \& Murphy, supra note 19, at 149; Lambert \& Larker, supra note 137, at 101. Compensation may be used to overcome differences in attitudes toward corporate risk and time horizons. Id.

139. Geoffrey Colvin, How to Pay the CEO Right, ForTUne, Apr. 6, 1992, at 60, 68.

140. Kenneth Mason, Four Ways to Overpay Yourself Enough, in EXECUTive CoMPENSATION, supra note 32, at 263, 271; see also Porter, supra note 46 , at 76 . Reform should focus on the creation of "a system in which managers will make investments that maximize the long-term value of their companies." Id.

141. See Michael Jensen, The Modern Industrial Revolution, Exit, and the Failure of the Internal Control System, 48 J. FIN. 831, 864 (1993) (proposing mcreases in both management and director investment in the company). 
indicate corresponding increases in long-term corporate value and may actually harm the company. The ownership ideal is often lost in the final product emanating froin the current executive compensation setting process. In fact, the pay-setting environment lends itself to potentially abusive transactions and less than efficient results, and the efforts of shareholders and the courts fail to alleviate the corporate governance ills.

\section{A. Pay-Setting Environment}

The theory of corporate governance is clear. Necessity dictates that someone must set the pay of corporate executives. In the ideal corporate environment, the shareholders elect directors, the directors choose executives, and executives handle the daily affairs of the corporation. ${ }^{142}$ Directors are responsible for the creation of executive pay packages; their fiduciary duty runs to shareholders. ${ }^{143}$ They act as proxies for the shareholders' interests in all decisions regarding the hiring and subsequent compensation of upper-level manageinent. Therefore, directors should be held accountable for any mistakes made in setting compensation. If shareholders dislike coinpensation decisions, they should oust the directors and thus confine executive pay to appropriate levels.

In reahty, compensation decisions of chief executives do not follow the ideal corporate governance nodel and occur in an environment that lends itself to self-dealing. ${ }^{144}$ While bearing the responsibility for compensation, the directors have a naturally existing business relationship with the executives, were probably recoininended for appointment to the directorship as a result of executive efforts, and may even be company executives that jointly serve as directors. Gratitude for their lucrative employment opportunity creates a type of "chicken or the egg" phenomenon which breeds loyalty to management and passivity among directors who become the corporate officer's 'lapdog, not the owners' watch-

142. See Walter J. Salmon, Crisis Prevention: How to Gear Up Your Board, HaRv. BUS. REV., Jan.-Feb. 1993, at 68 (outlining the two "crucial" functions of the board as corporate oversight and the compensation, selection, and evaluation of managenent).

143. E.g., Grahain v. Allis-Chalmers Mfg. Co., 188 A.2d 125 (Del. 1963).

144. See Samuel J. Silberman, CEO and Board Compensation Committee Concerns: $A$ Personal View, in EXECUTIVE COMPENSATION, supra note 32, at 347, 347 (describing the compensation decisions as the "most sensitive intersection of board and management roles and responsibilities"). 
dog."145 According to a $1993 \mathrm{Korn} /$ Ferry survey, director pay averages $\$ 33,133$ and can range as high as $\$ 60,000$ for the director's two weeks of yearly service. ${ }^{146}$ Few individuals would intentionally risk displeasing the person responsible for their participation in such a prestigious and economically rewarding part-time activity.

When corporate officers are also directors, their advice can carry a good deal of influence on the board. Thus, officers serving as directors often dominate the boardroom environinent. ${ }^{147}$ On the other hand, directors who are not corporate officers serve for only a few weeks per year for a short overall tenure, often come froin coinpletely unrelated business backgrounds, lack a private personal staff, and soinetimes split their time between the boards of several corporations. ${ }^{148}$ The advice of executives on the board, who are nore familiar with the intricacies of the business and have access to corporate information, may often be heeded by the board in all of its decisions. In the vast majority of American public corporations, the chairman of the board is also the CEO of the company. ${ }^{149}$ This American practice, in which less than $20 \%$ of public corporations separate the two roles, stands in stark contrast to foreign countries such as Britain where a full $70 \%$ of public companies utilize different individuals for these positions. ${ }^{150}$ The powerful joint position can harm corporate governance. ${ }^{\text {is } 1}$ CEOs may use their influence to appoint personal friends or individuals supportive of their positions to directorships. ${ }^{152}$ Survey results found that $89 \%$ of the compamies questioned depend on the clrairman's recommendation in selection of

145. Bogus, supra note 42, at 38; see also Porter, supra note 46 , at 76 (noting that systemic pressures lead "objective" directors to side with management).

146. Salmon, supra note 142 , at 74 . Directorships make an especially attractive retirement activity for some people. Arch Patton, Those Million-Dollar-a-Year-Executives, in EXECUTIVE COMPENSATION, supra note 32 , at $43,50$.

147. Salmon, supra note 142, at 69 . Corporate observers suggest limiting their numbers. Id. (proposing that there be only three representatives: the CEO, the Chief Operations Officer (COO), and the Chief Financial Officer (CFO)).

148. Crystal, supra note 32, at 226; Patton, supra note 146, at 49-51.

149. Jay W. Lorsch \& Martin Lipton, On the Leading Edge: The Lead Director, HARV. BUS. REV., Jan.-Feb. 1993, at 76.

150. Id.

151. See Jensen, supra note 141 , at 866 (noting that a consolidation of authority conbined with an unwieldy board of more than eight members allows management to make inefficient decisions).

152. CRYSTAL, supra note 39, at 226. 
directors. ${ }^{153}$ The joint CEO-chairman role thus allows executives to control the agenda-setting power and to substantially control the board's discussion and operations.

In practice, some attempts are made to counter the self-dealing nature of executive compensation decisions. Eighty-four to $99 \%$ of large compames form compensation committees to establish executive pay. ${ }^{154}$ Companies try to fill committees with the directors who have the least amount of outside ties to the executives, which means for the most part that the directors selected are not corporate employees. ${ }^{155}$ The primary motivation for employing outside directors on the compensation committee is the limitation of liability for the entire board because the law affords certain protection to decisions ratified by disinterested directors. ${ }^{156}$ Independent pay consultants propose the specific plans. The executives may also be represented by their own negotiators in dealings with the committee.

Yet, these safeguards only restrict egregious procedural abuses. Even "disinterested" committee members have incentives to favor upper-level management since the directors inust deal personally with the same officers throughout their respective tenures on the board. In addition, although "ostensibly being hired by a company's shareholders," executives usually select the actual pay consultants. ${ }^{157}$ Consultants recognize who effectively wields the power to hire thein and understand that pleasing the corporate officers may allow them to return for the next opportumity to set executive pay. For corporate boards, assuming that outside-pay consultants are independent can be a serious mistake. ${ }^{158}$

Another problem may be created by the fact that executive pay consultants represent a societal subgroup accustomed to a norm of incredibly high salaries. ${ }^{159}$ The pay consultants, equipped with their coinparison surveys of other top executive pay, present a persuasive argument to most self-respecting directors who cer-

153. Salmon, supra note 142 , at 71 .

154. James W. Fisher, Jr., The Role of the Compensation Committee, in EXECUTIVE COMPENSATION, supra note 32 , at 366,366 .

155. Barris, supra note 20 , at 75 .

156. Id.

157. CRYSTAL, supra note 39 , at 220.

158. See Graef S. Crystal, CEO Compensation: The Case of Michael Eisner, in EXECUTIVE COMPENSATION, supra note 32 , at $353,364-65$.

159. Barris, supra note 20 , at 77 . 
tainly do not want to pay their CEO less than the mean compensation for other high quality busmess talent. The result is constant upward pressure on pay levels. ${ }^{160}$ The inflationary impact on pay levels leads analysts to frequently urge compensation committees to refrain from engaging im a "parallel the market strategy."161 Executives can become the company's trophy. Unfamibarity with the corporation, combined with time and resource constraints, restrict the directors' ability to estabhish pay packages and select adequate corporate ineasures upon which to gauge pay properly. In fact, directors may be using their own compensation as a reference point for inanagement pay. Although the size of the firm itself could be the best determinant of executive pay levels, studies regularly find that executive coinpensation varies with the level of director pay. ${ }^{162}$ Movements of the two levels of compensation bear a sort of "incestuous" relationship. ${ }^{163}$ Since many chief executives also serve on the boards and compensation committees of other companies, they can provide a unique inutual "backscratching" environment for each other's pay. ${ }^{164}$

The process results in a lack of an "arm's length" bargaining environment, which merely adds to the controversy surrounding executive pay. Any comparisons in pay level with other nembers of society seem inappropriate. ${ }^{165}$ Executives, unlike other highly paid professionals such as athletes and performers, cannot demonstrate market inechanisms that help establish their compensation when they sit down with their agents to negotiate at arm's length.

160. CEO Pay: How Much Is Enough?, supra note 41, at 136.

161. Fisher, supra note 154, at 375 .

162. E.g., Charles O'Reilly et al., CEO Compensation as Tournament and Social Comparison: A Tale of Two Theories, 33 ADMIN. SCI. Q. 257 (1988) (finding greater correlation between CEO compensation and that of outside directors, especially compensation committee members, than between CEO compensation and size or performance indicators). But see Peter F. Kostivik, Firm Size and Executive Compensation, 25 J. HUM. RESOURCES 90 (1990) (utilizing firm size as a successful determinant of the level of executive income).

163. CRYSTAL, supra note 39, at 230.

164. Thomas McCarroll, Executive Pay: The Shareholders Strike Back, TIME, May 4, 1992, at 46, 47-48 ("It's a cozy you-scratch-my-back-I'll-scratch-yours arrangement . . . . [CEOs] don't want Mother Theresa or the Sisters of Charity on [their] compensation committee.").

165. CRYSTAL, supra note 39, at 31-41 (focusing on examples of sports figures, partners in law firms, and investment bankers). Soine analysts propose solutions to try to inake the executive pay-setting process more like that of other individuals. E.g., Martin, supra note 19, at 238-39 (advocating efforts to set CEO pay at arm's length like everyone else who "work[s] for a living," rather than as the "family business' favored child"). 
In other professions, high-pay levels may be legitimized by the genuine bargaining efforts that accompany their attainment. Additionally, unlike the majority of the workforce, high-level management does not face a true threat of dismissal. The firm-specific knowledge demanded in the chief executive's job ensures that most top managers will usually rise from within the company's ranks. Several studies have found a lack of cross-firm mobility within the market for CEOs and an average tenure of twenty-four years for top executives. ${ }^{166}$ The requirement of corporate familiarity reduces the available talent pool for the CEO position and only can increase the general reluctance of directors to replace their chief officers.

Although boards possess the power to do so, they rarely dismiss CEOs for purely performance reasons. ${ }^{167}$ Director relationships with management and a lack of adequate successors have led some companies, such as USAir, to retain their CEOs despite continued financial floundering. ${ }^{168}$ When a board actually removes the CEO for poor performance, the action might be too late since significant harm often has already been done to the corporation. ${ }^{169}$ In addition, the CEO terminations that do occur may be largely imdependent of performance. Boards even remove some chief executives despite the company's financial success and the officer's reputation in the business community as a "laudable exaniple of corporate management." ${ }^{\text {"170 }}$ Most CEOs, however, enjoy

166. E.g., Kostivik, supra note 162 , at 104.

167. Jensen \& Murphy, supra note 19, at 142 (noting research that only 20 of 500 management changes studied were performance-based terminations); Joann S. Lublin \& Christina Duff, Management: How Do You Fire a CEO? Very, Very Slowly, WALL ST. J., Jan. 20, 1995, at B1 (citing nationwide boardroom "reluctance to fire" chief executives).

168. Lublin \& Duff, supra note 167, at B1 (remarking that USAir, which has not had a profitable year since 1989, suffered 1994 losses in excess of “1993's $\$ 350$ million"). Some particularly disinal performances result in dismissal, as in the case of Interleaf, where a year of slumping sales followed by more than a $29 \%$ single-quarter "nose-dive" in volume led the board to believe "it had to take action." Interleaf Loses $\$ 8$ Million, Ousts Ruport as CEO, SEYbOLd REPORT ON PUBLISHING SySTEMS, Aug. 9, 1994, at 39. Ethically questionable behavior can also lead to a CEO's ouster. E.g., Joan E. Rigdon, Fatal Blunder: Genentech CEO, a Man Used to Pushing the Limit, Exceeds It and Is Out, WALL ST. J., July 11, 1995, at A1, A6. Often the poorly performing CEOs who face dismissal are especially high profile figures. Morrison Knudsen's dismissal of William Agee upon the report of the company's $\$ 150$ million fourth quarter loss in February 1995 exemplifies board actions taken against celebrated chief executives. Rigdon \& Lublin, supra note 87 , at $\mathrm{B} 1, \mathrm{~B} 4$.

169. Lublim \& Duff, supra note 167, at B1; see also Jensen, supra note 141, at 863 .

170. Sunbeam CEO Fïred, Partners Sue, WORLD NEws DIG., Feb. 25, 1993, at 118-A2; 
a lengthy average tenure with a minimal termination risk. One study showed that the average CEO has already been in office 6.5 years, and other studies have shown that the typical CEO will act as chief executive for a total of ten years. ${ }^{171}$ CEOs in companies enjoying the best performance face a $3 \%$ chance of termination while those in the worst inerely have a $6 \%$ risk. ${ }^{172}$ The net effect is that chief executives are thoroughly, and perhaps inextricably, engaged in their influential positions and in the process of the developinent of their own compensation.

\section{B. Shareholder Influence Through Self-Help Remedies}

One might expect restraints on pay to coine from downward pressure on share price through the inarket transactions of dissatisfied shareholders. In any decision, shareholders have the right to utilize the Wall Street Rule and "vote with their feet."173 Yet, the alternative of selling their stock may not be of much assistance to those institutional imvestors who inaintain indexed portfolios and cannot afford to sell their shares without significantly liarming their overall diversification strategies. ${ }^{174}$ Due to the large concentration of the country's capital in the holdings of institutional investors, ${ }^{175}$ the sale option plays less than its potential role in the inodern niarket. Furthermore, high transaction costs and a negative impact on the corporation that may not clearly inanifest itself can also dissuade investors with snialler portfohos from action in conıpensation inatters.

The soinewhat illiquid interest of an institutional investor in a corporation, however, inay create enough incentive for the shareholder to seek to influence corporate policy. Investors possess several options to indicate their preference in the coinpany's deci-

see also Amy Feldman, Position Wanted, Forbes, Feb. 28, 1994, at 16 (describing dismissal of CEO of Andes Candies on the same day that Forbes complimented her for "turning around" the company).

171. Anders, supra note 1 , at 81 .

172. Jensen \& Murphy, supra note 19 , at 142.

173. Martin, supra note 19 , at 239.

174. See Robert C. Pozen, Institutional Investors: The Reluctant Activists, HaRv. BUS. Rev., Jan.-Feb. 1994, at 140, 147. The California Public Employees Retirement System (CalPERS), for example, maintains a highly indexed portfolio with a single largest 1990 holding of merely $.71 \%$ of a particular company's equity. Porter, supra note 46 , at 69 .

175. Straka, supra note 131, at 807-08; Michael Siconolfi, Individual Investors' Holdings of U.S. Stocks Fall Below 50\% of Total Market for the First Time, WALL ST. J., Nov. 13, 1992, at C1. 
sions, such as engaging in proxy fights, proposing shareholder resolutions, and commurricating with the corporation. ${ }^{176}$ An institutional investor represents a consohidated voting block of corporate authority. Negotiations backed by the threat of a vote have the potential for profound impact on corporate policy decisions. Large private investors, such as Kirk Kerkorian, and their influence on the operations of some of America's largest corporations offer examples of mvestor power short of any vote or sale of stock. Although Kerkorian does not maintain a controlling interest im Chrysler's equity, his constant pressure forced the company to "share the cash stockpile it [had] been amassing" by raising its dividend $60 \%$, repurchasmg one billion dollars of stock, and lowering a poison pill defense. ${ }^{177}$ The same type of shareholder pressure can be seen in the efforts of the New York City pension fund and other institutional imvestors to force RJR Nabisco to separate its food and tobacco busmesses. ${ }^{178}$ Some analysts believe that institutional investors offer the "best available watchdog" for corporate governance. ${ }^{179}$ SEC policy on executive compensation matters certainly focuses on shareholder influence as the proper method of addressing the issue. ${ }^{180}$

Notwithstanding the SEC's faith in sliareliolders, many analysts question the net effects of shareholder influence on business given the shareholder's lack of long-term focus and managemeut experience. ${ }^{181} \mathrm{~A}$ few of the nation's largest institutional mvestors lave acted on compeusation issues. ${ }^{182}$ However, little shareholder

176. Pozen, supra note 174 , at $146-47$.

177. See Neal Templin \& Nichole M. Christian, Chrysler Boosts Dividend, Sets Buyback of Stock in Effort to Mollify Kerkorian, WALL ST. J., Dec. 2, 1994, at A3.

178. Glenn Collins, New Pressures on Philip Morris, N.Y. TIMES, Sept. 21, 1994, at C1; cf. Arthur M. Louis, Struggling Real Estate Developer Fires CEO, S.F. CHRON., Feb. 15, 1994, at D1 (discussing similar influence exercised by CalPERS at Eastman Kodak, General Motors, IBM, and Catellus Development Corp.); Michael J. McCarthy, UAL Reaches New Agreement on Buyout Plan, WALL ST. J., May 23, 1994, at A3 (noting role of institutional mvestors in negotiation of terms of the airline's employee buyout).

179. Barris, supra note 20, at 100; see also Dale M. Hanson, The Bureaucrats Strike Back, HARV. BUS. REV., Jan.-Feb. 1993, at 78 (claiming that institutional investors can, and do, examine performance statistics over the longterm) (author is CEO of CalPERS).

180. See supra text accompanying notes 117-35.

181. E.g., Porter, supra note 46, at 67-68 (expressing concern with the short-term horizons of all American investors); Charles Wohlstetter, Pension Fund Socialism: Can Bureaucrats Run the Blue Chips, HARV. BuS. REV., Jan.-Feb. 1993, at 78 (noting the lack of pension fund einployees with a "background in major corporate management").

182. In recent years, CalPERS actions liave targeted sucl companies as ITT, UAL, 
activity has occurred overall with respect to executive compensation issues. In fact, when issues of all subject matter are considered, even the "outspoken" CalPERS becomes involved in less than thirty companies per year. ${ }^{183}$ In order to satisfy their fiduciary duties to imvestors, institutional owners weigh the costs of activism against the potential benefits. ${ }^{184}$ Momitoring a particular company's compensation decisions can be costly and difficult for mstitutional mvestors. ${ }^{185}$ Moreover, since compensation decisions normally do not present a clearly negative impact on its diversified holdings, an mstitutional investor is much more likely to focus its resources on its investment strategy: "The reality is that it's very difficult for even a large institutional investor to develop the resources to go into every issue."186 In addition, involving shareholders inore directly in the initial process of compensation may not produce the best results. Shareholder influences in the pay-settimg process could lead to unnecessary confusion of policies and to shareholder and SEC micromanagement of executive-compensation decisions. ${ }^{187}$ An efficient and beneficial compensation policy could be developed through the mere shareholder threat of a genuine post-decision review of board actions in the pursuit of a legal remedy. Unfortunately, derivative legal action has not proven an effective influence on compensation practices.

General Dynamics, and Fairchild. See Brownstein \& Panner, supra note 17, at 34; Yablon, supra note 137, at 1889-90 n.61. Other pension funds such as those run by New York City and Wisconsin have also addressed compensation issues. CEO Pay: How Much Is Enough?, supra note 41, at 139 (describing shareholder resolution filed by New York City Employees Retirement System to limit the membership of compensation committee at Reebok International to outside directors); Pozen, supra note 174, at 145 (outlining efforts of State of Wisconsin Pension Board to convince shareholders to withhold votes for compensation committee at Paramount Communications).

183. Pozen, supra note 174 , at 147.

184. Id. at 141 .

185. Yablon, supra note 137 , at 1892 .

186. Lauren Young, The Owner Mentality, WALL ST. J., Apr. 12, 1995, at R12 (quoting Philip Halpern, Chief Investment Officer for the Wasltington State Investment Board).

187. Martin, supra note 19, at 253. Courts may strike down SEC micromanagement and certain "shadings within the notion of 'management." Business Roundtable v. SEC, 905 F.2d 406, 411 (D.C. Cir. 1990) (ruling against the SEC's authority to mandate a one slrare-one vote requirement for stock). 


\section{Shareholder Influence Through Derivative Legal Action}

In theory, shareholders may enforce their fiduciary duty rights through legal action. Given the ineffectiveness of the corporate model itself and the self-help mechanisms, legal liability may constitute the only motivation for corporate actions. The current influence of legal action, however, is limited. In attempts to pursue a judicial remedy, shareholders face procedural challenges within a court system that offers high levels of protection to compensatiou decisions. ${ }^{188}$ The protection of the board's decisions is two-fold: Plaintiffs must overcome the initial hurdle of the demand requirement only to face the second obstacle of the business judgment rule.

Since a shareholder's injury is derivative in nature, the plaintiff must bring suit in the corporation's name. Procedure dictates that the shareholder make a demand on the corporation's directors to rectify the situation. ${ }^{189}$ The procedural demand issue can dictate the outcome of the substautive issues in the case. Geuerally, the only instance in which demand can be overcome is when demand is excused under the futility exception because of a transparent self-dealing environment. ${ }^{190}$ Plaintiffs need to demonstrate more than just the mere fact that the decisionmakers were elected and serve at the behest of individuals who control the outcome of corporate elections, especially simce directors may accept management input into their. decisions. ${ }^{191}$ If the compensation plan has been ratified by disinterested directors, excusal of demand will be highly unlikely. Because the decision to excuse demand is determined at the time of the filing of the complaint, plaintiffs do not benefit from full discovery, further adding to the difficulty of their task. ${ }^{122}$

Once past the demand stage, the shareholder must face the second obstacle of the business judgment protection, regardless of the theory on which the claim is based. ${ }^{193}$ The shareholder claim

188. Martin, supra note 19 , at $243-44$.

189. E.g., Aronson v. Lewis, 473 A.2d 805, 811-12 (Del. 1984).

190. Id. at 814 .

191. Id. at 814-15.

192. 2 JAMES D. COX ET. AL., CoRporations $\S 15.7$, at 15.62 (1995).

193. E.g., International Ins. Co. v. Johns, 874 F.2d 1447, 1458-61 (11th Cir. 1989) (articulating principle of the business judgment rule under which the board of directors maintains broad discretion over business decisions and enjoys the presumption that the directors behaved properly and in good faith). 
may proceed on either a theory of fiduciary duty violation or one of corporate waste. ${ }^{194}$ Fiduciary duty consists of a two-part director duty: a duty of loyalty and a duty of care. Compensation decisions do not clearly violate the loyalty aspect of the fiduciary duty. Although officer compensation contaims self-dealing elements, a court may not view such decisions as expressly implicating the duty of loyalty. ${ }^{195}$ Shareholders may hope these aspects of selfdealing, taken in conjunction with the second element of the fiduciary duty (i.e., the directors' care requirement), will offer them some rehef. A successful attack of a pay decision, however, is also unlikely since the business judgment rule applies to protect the compensation selections of the corporation. ${ }^{196}$

Under the fiduciary duty concept, an executive compensation decision is considered a routine business transaction. Procedural requirements of the directors to satisfy busmess judgment protections with regard to compensation decisions remain relatively low compared with those applicable to such fundanental transactions as mergers and consolidations. ${ }^{197}$ If directors employ the usual process of purportedly dismterested compensation committees, the compensation decision will have to be shown to be devoid of any rational basis $\mathrm{m}$ order to establish liability. ${ }^{198}$ Plaintiffs face a "Herculean" labor and rarely succeed in overcoming this high standard. ${ }^{199}$

194. See, e.g., id.; Cohen v. Ayers, 596 F.2d 733, 739 (7th Cir. 1979); Michelson v. Duncan, 407 A.2d 211, 216-17 (Del. 1979); Wilderman v. Wilderman, 315 A.2d 610, 615 (Del. 1974); Beard v. Elster, 160 A.2d 731 (Del. 1960); see also John F. Olson et al., The Board Compensation Committee Report on Executive Compensation: The Effect on the State Law Fiduciary Duty of Directors, in EXECUTIVE COMPENSATION REPORTING, supra note 97, at 305, 308-14 (1993).

195. See, e.g., Cohen, 596 F.2d at 739-40 (focusing analysis on loyalty effect upon burden of proof for the care duty).

196. See, e.g., International Ins. Co., 874 F.2d at 1461; Freedman v. Barrow, 427 F. Supp. 1129, 1155 (S.D.N.Y. 1976); Haber v. Bell, 465 A.2d 353, 357 (Del. Ch. 1983).

197. See Smith v. Van Gorkom, 488 A.2d 858, 874 (Del. 1985) (requiring directors to become informed in merger transaction). Unlike a case involving fundannental transactions, there is a long tradition of executive compensation issues being within the "business and affairs" of the corporation managed by the board. Id. at 872. See also Unocal Corp. v. Mesa Petroleum Co., 493 A.2d 946955 (Del. 1985) (noting that in creating a takeover defense, board's decision must be "reasonable in relation to the threat posed").

198. Yablon, supra note 137, at 1883; Olson et al., supra note 194, at 311-14.

199. Bogus, supra note 42, at 22; see also Cohen, 596 F.2d at 738-39 (approving an option repricing); Pogostin v. Rice, 480 A.2d 619, 627 (Del. 1984) (upholding stock option plan adopted by a majority of disinterested directors); Beard v. Elster, 160 A.2d 731, 
Alternatively, a shareholder may sue under a corporate waste theory. The shareholder must demonstrate that the company failed to receive reasonable consideration for the resources it expended. ${ }^{200}$ Even shight consideration will justify the directors' compensation decisions, ${ }^{201}$ and the reasonableness requirement can be met easily if the board purports to award the compensation payments for an appropriate purpose such as to reward and retain the executives. ${ }^{202}$ Only the most egregious compensation relationships will be prohibited. ${ }^{203}$ Shareholders have had httle success in overcoming the minimal consideration standard. ${ }^{204}$ As a result, when the company receives some type of consideration, the directors rely on the advice of compensation experts, and a committee of outside board members approves the package; thus, pay decisions enjoy near complete insnlation from the legal actions that could compensate for the structural deficiencies in the executive pay determination process. ${ }^{205}$

Given the imperfections of the pay-setting environment and the futility of self-help and legal actions, shareholders have few effective avenues for remedying perceived excessive compensation. Ownership interests have diverged from those of management, and

738 (Del. 1960) (protecting option plan approved by disinterested directors).

200. Saxe v. Brady, 184 A.2d 602, 610 (Del. Ch. 1962) (outlining the classic test for corporate waste as the receipt of consideration "so inadequate in value that uo person" of ordinary, sound business judgment would deem it worth what the corporation has paid").

201. Heller v. Boylan, 29 N.Y.S.2d 653, 680 (N.Y. Sup. Ct. 1941).

202. Barris, supra note 20, at 81,84 (finding few cases and less analysis relating to instances of corporate waste in compensation payments where some service was rendered).

203. See Rogers v. Hill, 289 U.S. 582, 591-92 (1933) ("If a bonus payment has no relation to the value of services for which it is given, it is in reahity a gift in part and the majority stockholders have no power to give away corporate property against the protest of the minority." (quoting Rogers v. Hill, 60 F.2d 109, 113-14 (2d Cir. 1932) (Swan, J., dissenting)). Bonuses will not be permitted wheu they are "so large as in substance and effect to amount to spoliation or waste of corporate property." Rogers, 289 U.S. at 591.

204. E.g., International Ins. Co. v. Johns, 874 F.2d 1447, 1469 (11th Cir. 1989) (holding incentive plan not to constitute waste because it encouraged workers to remain with company and continue to act in its best interests); Cohen v. Ayers, 596 F.2d 733, 739 (7th Cir. 1979) (finding the decision of cousideration adequacy for a stock option repricing within the "sound business judgment of the corporation's directors"); Pogostin v. Rice, 480 A.2d 619, 626 (Del. 1984) (upholding stock option plan as sone beuefit had accrued); Olseu Brothers Inc. v. Englehardt, 245 A.2d 166, 168 (Del. 1968). But see Rogers, 289 U.S. at 582 (holding generous, 20-year-old bonus formula to constitute waste); Kerbs v. Califormia Eastern Airways, 90 A.2d 652, 657 (Del. 1952) (striking certain stock options that had no continued employment requirement and no vesting period).

205. Barris, supra note 20 , at 86 . 
the operation of the corporate model has not succeeded in realigning them. Managers do not think like long-term proprietors. Moreover, they have no economic incentive to do so because compensation inay be set in a self-dealing environment largely free from shareholder repercussions. The problem is clear: Corporate governance has failed in this respect.

\section{Proposal-The Solution of OWNERSHIP AND JUDICIAL REVIEW}

As the business world copes with the issues of executive coinpensation, focus inust shift from the symptom to the underlying corporate governance problein. Current pay-for-performance programs should be revised because the problem demands a flexible implementation derived from the ideals of true long-term ownership. Regulatory entities inust refram from pushing a bureaucratic performance solution; rather, they should allow a sufficient judicial forum and legal incentive for reform. The floodgates of litigation need not be thrown open as a few key decisions could establish standards that inost corporations would follow. Moreover, by altering procedural protections in coinpensation cases, courts could allow actual analysis of certain pay decisions to ensure independence of decisionmaking and the advanceinent of ownership interests.

\section{A. An Ownership Basis}

The federally advocated performance-based system atteinpts to be a proxy for ownership, but artificial substitutes are not capable of simulating true long-term ownership. Attempts to inamipulate managerial behavior by tying compensation to individual economic indicators may fail and certainly will bring risks of added harm to the corporatiou. Pay plans should be viewed for what they are-coinpensation. The focus needs to shift from encouraging and micromanaging certain aspects of performance to achieving true long-term proprietary interests. Reform efforts should encourage chief executives to own significant amounts of equity. ${ }^{206}$ Officers' holdings should be restricted and not capable of transfer for an extended period of time. The longer the executive's outlook is, the better it will be for the coinpany. The three to five-year limit on transferability for any restricted stock options offered in today's

206. E.g., Brownstein \& Panner, supra note 17, at 35. 
packages ${ }^{207}$ should be lengthened to an absolute minimum of five years. Multiple benefits would accrue by overcoming America's problem of "transient ownership" and "linking pay more closely to long-term coinpany prosperity."208 Indeed, the potential benefits of ownership can be seen in survey results that indicate that companies with above-median levels of stock ownership among their chief executives enjoy higher returns than those of companies with below-inedian ownership. ${ }^{209}$ Ownership efforts should be expanded, and executives should be required to ride the corporate enterprise's rollercoaster of fortune. There can be no better way to sunulate a proprietary experience than to offer it. Purported performance plans may take a variety of forms, but ownership represents a basis against which such plans should be balanced. The contribution to true long-term ownership interests would help to provide an effective measurement.

Ownership plans might be initiated by forcing equity on executives at their initial engagement: "Putting one's own money at stake seems like a sound approach to incentives."210 Indeed, soine companies, such as corporate takeover giant Kohlberg, Kravis, Roberts \& Co. (KKR), have achieved positive results by asking top managers to purchase or hold a large proprietary interest in their company. When KKR acquired Duracell in 1988, the company's management increased its holdings froin $1 \%$ to $9.85 \%{ }^{211}$ In the period following the acquisition (1988 to 1992), company performance caused Duracell's stock price to rise over $\$ 20$ per share. ${ }^{212}$ Solne companies, such as Caterpillar Inc. and Corning Inc., even "pohice their employees' holdings" and "penalize" executives who do not meet proper stock-ownership levels. ${ }^{213}$

Increased executive ownership could be achieved in a more subtle manner through compensation. The specific form of long-

207. Lublin, supra note 28 , at $\mathrm{R} 4$.

208. Porter, supra note 46 , at 81 .

209. Young, supra note 186 , at R12.

210. Dumaine, supra note 29 , at 103 . An executive may respond favorably to the notion of a mandatory stock purchase in their company. E.g., Joann S. Lublin, Money Talks, WaLl ST. J., Apr. 12, 1995, at R10 (describing the situation of Scott Paper Co.'s CEO, Albert J. Dunlop, an avid proponent of a stock purchase requirement for new CEOs who bought $\$ 4$ million of stock when asked by the company's board to purchase $\$ 1$ million worth).

211. Anders, supra note 1 , at 80 .

212. Id. at 81 .

213. Young, supra note 186 , at R12. 
term equity utilized in such situations may vary. For instance, restricted stock grants with lengthy limitations on transferability offer one method of encouraging a proprietary position. In the alternative, corporations could offer stock options with reasonably low exercise prices and extremely lengthy vesting periods. Options represent relatively inexpensive proprietary substitutes when appropriately set to discourage short-term risk-taking and to allow rewards for steady long-term growth. Some critics fear that options offer incentives for executives to engage in potentially detrimental behavior to induce a rise in stock price above strike price. ${ }^{214}$ These risks, however, can be largely ehminated by awarding options that should return a payoff through merely moderate growth and by allowing sufficient vesting time in order to avoid any atteinpts at short-term inflation of share price. Excessive inanagerial risk usually will not constitute a problem as executives retain more of a stake in a particular company than do diversified imvestors. ${ }^{215}$

Similarly, the cost to the corporation of such compensation through the dilution of equity need not be large, notwithstanding the claims of certain critics. ${ }^{216}$ Executives must be paid in some form of compensation. Companies might as well compensate them in a manner that provides some return to the corporate enterprise. Managers who focus on the improvement of long-term corporate stock price will rapidly counter any dilutionary effects of options or additional equity allocations and outstrip the market cost of treasury share transfers as benefits accrue to all shareholders. Take, for example, the situation at Panhandle Eastern Corp., a company that has elected to compensate its CEO and chairman, Dennis R. Hendrix, entirely in stock. ${ }^{217}$ Although Mr. Hendrix's holdings had increased to 389,000 shares with a market value of mine million dollars as of April 1995, the firm's stock price had more than doubled from $\$ 11$ to $\$ 23$ million since he jomed the company in $1990{ }^{218}$ Shareholders will have difficulty finding fault in the level of the CEO's holdings when they continue to enjoy such returns.

214. E.g., CRYSTAL, supra note 39 , at 71 .

215. See supra text accompanying notes 99-100.

216. Andrew E. Serwer, Executive Pay: The Big Hangover in Stock Options, FORTUNE, July 24, 1995 at 28.

217. Young, supra note 186, at R12.

218. Id. 
Under this proposed method, the executive would be offered a fixed salary absent performance indicators for the remaining portion of compensation, thereby removing incentives to manipulate measures and harm the corporation. Executives could elect to receive all compensation as a guaranteed salary. The long-term incentives, however, should be offered at beneficial returns to make them attractive and to encourage the executive to take a sizable portion of compensation in this form. The salary allows the executive to receive his risk-free worth, but the long-term ownership offers much larger rewards. If an executive truly beheved in his personal abilities, lie would elect to receive compensation in the form of higher potential long-term returns. In order to reap the largest possible reward, executives would have to focus on the long-term success of the corporation.

Since attracting and retaining talented executives can be problematic, especially in a system with large amonnts of uncertain payoffs, the potential benefits of risk must outweigh the perceived costs of risk. Yet, as more than $70 \%$ of CEOs rise from within corporate ranks, offermg especially attractive CEO compensation may not be as important to the firm as one might mitially believe. ${ }^{219}$ Indeed, given the firm-specific nature of the CEO labor market, creating strong incentives to prevent corporate leaders from "being pirated by another company" may not be necessary. ${ }^{220}$ The retention argument may be just another excuse to justify overpayment of top level management. ${ }^{221}$ As one critic noted, certam corporate leaders such as "Jack Welch can get another job," but "[m]ost CEOs can't."222

\section{B. Judicial Implementation in Lieu of Federal Advocacy}

The corporate governance problem should be addressed through standards estabhshed in a judicial forum rather than those dictated by federal regulators. Some reformists have already recognized the potential benefits offered by judicial analysis. ${ }^{223}$ Only judicial remedies possess the necessary flexible approach that can

219. BoK, supra note 14 , at 105.

220. Id.

221. Lublin, supra note 28 , at R4.

222. Id. (quoting Stanford University Law Professor and former SEC Commissioner Joseph Grundfest).

223. E.g., Barris, supra note 20, at 87-88; Yablon, supra note 137, at 1906. 
encourage individual innovation and freedom in the implementation of compensation matters while simultaneously preventing abuses and addressing the problem of setting pay in the corporate environment. An adversarial process complete with an opportunity for discovery ${ }^{24}$ would prove beneficial in establishing standards that ensure genuine independence in the compensation process and the promotion of ownership interests. In a judicial forum, the compensation plan of the top executives and the decisionmaking process can be analyzed and debated rather than summarily penalized through tax laws and disclosure regulations. Moreover, a chilling effect will not override compensation innovation. If a corporation genuinely believes in its compensation scheme, it can elect to compensate executives in such a maimer and, if necessary, defend its sclieme in court.

Contrary to current practice, regulatory entities should refrain from advocating any type of compensation system. Notwithstanding the proposals by some critics of the current system that federal incentives must inerely encourage a different particular method of compensation, ${ }^{225}$ Congress and the SEC are not charged with dictating the direction of corporate governance in America. In addition, the country's limited federal resources ${ }^{226}$ should not be wasted on the development of "bureaucratic"227 solutions that do not resolve effectively problems of business strategy. Federally mandated approaches are too restrictive. ${ }^{228}$ Corporations employ many creative individuals who may design imnovative compensation schemes appropriate for their organizations. Who is to say that all such compensation must function on a performance basis? Instead, corporations should be encouraged to apply their own choices of compensation policy, within certain reasonable parameters, such as the prohibition of managerial self-dealing plans.

Congress and the SEC should follow the example of restraint established by the Financial Accounting Standards Board (FASB),

224. See supra text accompanying note 192.

225. E.g., CRYSTAL, supra note 39, at 249-51 (suggesting tax-based motivation for certain restricted options with 10-year vesting periods).

226. The SEC, for example, has recently operated with only two of five commissioners, creating an understaffing situation which significantly taxes the Commission's ability to address major issues and creates certain delay. Mark H. Anderson, SEC Members Now Count Only Two, WALL ST. J., July 17, 1995, at B4A.

227. Karmel, supra note 116, at 7.

228. See Yablon, supra note 137, at 1889-90. 
another regulatory entity that had the opportunity to enter the executive compensation debate. In June 1993, FASB addressed the executive compensation issue through the drafting of a proposal to change the accounting method for stock options. ${ }^{229}$ Altering the accounting standards for options, which constitute an important tool for the advancement of ownership interests, would have lowered reported earnings for compamies that utilize options as a compensation method. The proposed mandatory earnings charge would have greatly limited the use of options as a method of compensation, especially in smaller high-technology firms in which options often constitute a sizable portion of the pay of all employees. $^{230}$ After a lengthy debate that was analogized to the public controversies over "NAFTA, healthcare reform, and the designated hitter [rule]," ${ }^{, 231}$ FASB has resigned itself to footnote disclosure, a minor rule change that represents a substantial retreat from the position the Board staked out in the exposure draft. ${ }^{232}$ Following FASB's lead, Congress and the SEC should not advocate any particular compensation plan but instead should allow the investing commumity to negotiate the appropriate standards for the pay decisions through the judicial forum.

The true merit of the reforms arise, however, from the deterrent effect that genuine judicial analysis would provide. The legitimate threat of post hoc legal action would correctly guide boards and executives through the corporate decisionmakmg process. In addition, the disruptive effects of shareholder involvement in the imitial compensation decisions could be avoided. Ideally, httle extra hitigation would actually be necessary. Corporate counsel merely could alert management to the litigation risk in compensation decisions to ensure a fully informed, fair process. ${ }^{233}$

229. FASB, Proposed Statement of Financial accounting Standards, ACCOUNTING FOR STOCK-BASED COMPENSATION, (June 30, 1993), reprinted in EXECUTIVE COMPENSATION REPORTING, supra note 97 , at 403.

230. Dumaine, supra note 29, at 103; George Sollman, Debate: CEO Pay: How Much is Enough?, HARV. Bus. REv., July-Aug. 1992, at 130, 137; 140 Cong. Rec. S14,507, 14,509 (daily ed. Oct. 6, 1994) (statement by Sen. Lieberman).

231. Jay Mathews, Panel Gets an Earful on Stock Options Rule, WASH. POST, Mar. 8, 1994, at C2.

232. FASB to Issue Final Rule on Valuing Stock Options, WALL ST. J., July 28, 1995, at A3; Lee Berton \& Joann S. Lublin, FASB Softens Plan on Deducting Costs of Stock Options, WALL ST. J., Dec. 15, 1994, at A2, A9.

233. Yablon, supra note 137, at 1901. 
The court system was quite successful in developing appropriate standards of director behavior in response to the takeover environment of the $1980 \mathrm{~s}^{234}$ The Delaware courts clarified business judgment standards in acquisition situations through a series of decisions extending into the current decade. ${ }^{235}$ Similar progress could be made in compensation analysis. Although little effective review of pay decisions occurs today, an adjustment in procedural standards in the executive compensation area could lead to the establishment of effective guidance for pay decisions. If plaintiffs faced more than a minuscule opportunity of success in their endeavors, the same judicial system that currently insulates potentially abusive compensation decisions actually cquld act to curb them.

\section{Setting the Standards with Independence and Yardsticks}

Effective judicial review of executive compensation can be attained through an adjustment to procedure. The self-dealing nature of pay decisions demands that courts examine such decisions unore thoroughly than other genuinely arm's lengtlı business actions. A demand-like hearing involving certain minimal discovery rights and a mini-review on the inerits of the case would allow courts to estabisli the necessary standards in the executive compensation field. Legitimate discovery rights would prevent sharelıolders from being locked out of the courthouse merely because they lack a minimal amount of compensation information. A suminary examination of the merits based upon a sufficiency standard would allow plaintiffs with a genuine case to overcome the double procedural barriers of demand and the business judgment rule. A plaintiff that cleared the abbreviated review process would not need to overcoine the business judgment presumptions.

The judiciary is competent to handle a mini-merit review of executive compensation issues. Compensation decisions are matters of economics. By their very nature, they are inuch more objective than the resolution of classic business issues such as whether base-

234. Id. at 1898-99; e.g., Smith v. Van Gorkom, 488 A.2d 858 (Del. 1985) (setting standard of informed decision); Unocal Corp. v. Mesa Petroleum Co., 493 A.2d 946 (Del. 1985) (requiring a reasonable relationship to threat).

235. See Paramount Communications v. QVC Network, 637 A.2d 34 (Del. 1993); Paramount Communications v. Time, Inc., 571 A.2d 1140 (Del. 1990); Revlon, Inc. v. MacAndrews \& Forbes Holdings, 506 A.2d 173 (Del. 1986); Smith, 488 A.2d at 858; Unocal, 493 A.2d at 946. 
ball should be played at nighttime. ${ }^{236}$ Full business judgment protection is not needed for compensation decisions nor is it neerited given the largely self-dealing environment in which compensation decisions are set. Moreover, courts already conduct thorough reviews of compensation in certain tax cases ${ }^{237}$ and those involving close corporations. ${ }^{238}$ Review in executive compensation cases need not even reach such a level.

A company's compensation decisions should be protected in the mini-review process if they are delivered by truly independent consultants or actually denionstrate the genuine proprietary interest that they claim to offer. Boards that still want to defer to compensation consultants should be allowed to do so, notwitlstanding all the upward biases and needless resource consumption involved in their use. However, board inembers nust not be allowed to rely blindly on the purported independence of such consultants. Self-dealing should be closely inointored. Consultants certainly slould not be commissioned by nianagement. Limits and firewalls must be established for recurring engagennents. Although a consultant niay propose the scheine, the board must ultimately bear the responsibility.

Some types of compensation itself should be sufficient to withstand the mini-review and maintain the procedural protections. The caveat, of course, would be that such compensation compares favorably with the principle of genuine long-tern ownership, and courts need to engage in such a coniparative analysis. Courts inay complain that they lack a "yardstick" by which to measure executive compensation. ${ }^{239}$ However, such a yardstick exists in the

236. See Schlensky v. Wrigley, 237 N.E.2d 776 (Ill. App. Ct. 1968).

237. Courts consider many factors such as an employee's qualifications, the nature and complexity of the business, and return on equity to determine whether compensation qualifies as a "reasonable" expense entitled to deduction under I.R.C. § 162(a)(1) (1995). E.g., RTS Investment Corp. v. Commissioner, 877 F.2d 647 (8th Cir. 1989); Rutter v. Commissioner, 853 F.2d 1267 (5th Cir. 1988); Ownersby \& Kritikos, Inc. v. Commissioner, 819 F.2d 1315 (5th Cir. 1987); Elliotts, Inc. v. Commissioner, 716 F.2d 1241 (9th Cir. 1983); Kennedy v. Commissioner, 671 F.2d 167 (6th Cir. 1982); Mayson Manufacture Co. v. Commissioner, 178 F.2d 115 (6th Cir. 1949); Pfeiffer Brewing Co. v. Commissioner, 11 T.C.M. (CCH) 586 (1952).

238. E.g., Cookies Food Products v. Lakes Warelıouse Distributing, 430 N.W.2d 447 (Iowa 1988); Hingle v. Plaquemimes Oil Sales, 399 So.2d 646 (La. Ct. App.), cert. denied, 401 So.2d 987 (La. 1981); Miller v. Magline, Inc., 256 N.W.2d 761 (Micl. 1977); Fendelinan v. Fenco Handbag Manufacturing Co., 482 S.W.2d 461 (Mo. 1972); Salus v. Troy Donut Univ., Inc., 460 N.E.2d 310 (Ohio Ct. App. 1983); Bermann v. Meth, 258 A.2d 521 (Pa. 1969); Lyncli v. Patterson, 701 P.2d 1126 (Wyo. 1985).

239. See, e.g., Heller v. Boylan, 29 N.Y.S.2d 653, 680 (N.Y. Sup. Ct.), affd, 32 
form of extended inalienable ownership. Simulated ownership is what directors purport to offer executives, and the very existence of performance pay begs the question of why one does not offer genuine ownership. Indeed, ownership itself should be the yardstick for coinpensation.

The proposed test adds a step to compensation analysis. In order to obtain full protection of their decisions, directors must be capable of demonstrating that coinpensation packages either were set in an entirely independent inanner or compare favorably to long-term ownership interests. The partial self-deahing aspects inherent in compensation decisions demand such a supplemental requirement. Implementation inethods would be free to vary as the courts provide the opportuuity to evaluate individual methods of ownership and compensation im general. Boards and compensation committees still would enjoy all of the previous procedural protections provided that they meet the requirements of legitimate independence or genume ownership. In addition, directors could still justify plans which do not represent proprietary principles. Boards, however, would lack full business judgment protection for such decisions, and plamtiffs would at least be able to question the legitimacy of pay packages.

Many proposals wrongly suggest inaximizmg the number of dismterested directors on the board and the compensation committees. ${ }^{240}$ Although certain initial improveinents inay be made by separating the key role of chairman from that of CEO, as in the United Kingdon, ${ }^{241}$ increasing the number of other directors with no ties to the busmess as well as the executives may be detrimental to the corporate enterprise on the whole and even to the pay decision itself. Outside directors suffer froin certain disadvantages in their relationship with executives, often remain passive in boardroom decisionmaking, and usually choose to ahgn theinselves with management. Nonemployee directors know less about the corporation, its business, and its pohcies. Therefore, they possess less

\footnotetext{
N.Y.S.2d 131 (N.Y. App. Div. 1941).

240. E.g., CEO Pay: How Much Is Enough?, supra note 41, at 131-34 (solutions offered by the president of the United Shareholders Association and the National Director of Compensation and Benefits Consulting for Arthur Andersen \& Co.); Lorsch \& Lipton, supra note 149, at 78-80 (statements by managing vice-president of Korn/Ferry Consulting and the Chair of the British Committee on Fmancial Aspects of Corporate Governance); Dodell, supra note 97, at 226; Martm, supra note 19, at 244.
}

241. See supra text accompanying notes 150-52. 
knowledge about the worth of a particular individual's services. In addition, the board needs to include some executives in order to add their "invaluable" input to other corporate decisions. ${ }^{242}$ While appearing to be less interested, nonemployee directors inay suffer from inany of the same biases as einployee directors, such as working closely with the executives, relying upon executive support for their decisions, and depending on executives for their continued position on the board. A corporate board with more nonemployee directors may be a worse supervisory entity because it appears to be less susceptible to manipulation when the reality is otherwise.

In the end, someone inust decide what executives will be paid. A judge may count the noses of facially disinterested directors, but what the director brings to the analysis is more important than his place of business and outside contacts; what the director does in the decisionmaking process is the crucial factor. Bringing in outside compensation consultants inay be an indication of true analysis. However, courts inust recognize the potential for management biases even in the recommendations of outside consultants. The board should not substitute a compensation consultant's proposals for its own common sense.

The changes in procedure would not represent a slippery slope towards the end of judicial deference in business decisions. The newly established procedure would be limited to the executive compensation area, an area which demands reforn given its selfdealing nature. As inentioned above, such decisions are also different from the vast majority of issues facing corporate America in that they can be resolved in a largely objective inanner. Executive compensation issues should constitute an express exception from full-business protection. The limitation on protection would be similar to the adjustments in corporate law, that occurred through the antitakeover decisions. ${ }^{243}$ As with the antitakeover rulings, the executive compensation decisions would be confined in apphication to a specific environment-pay-setting decisions in the public corporation. Moreover, legitimate coinpensation of any nature could be utilized as long as it was defensible.

Ownership is the answer. In order to look beyond the symptoin of high aggregate compensation levels and address the prob-

242. Salmon, supra note 142 , at 69 .

243. See supra text accompanying notes 234-35. 
lems of corporate governance, courts should encourage boards to employ a proprietary interest regardless of its exact form. Regulatory advocacy of the ineffective and potentially detrimental performance packages must cease. Indeed, an effective judicial doctrine based upon ownership coinparisons and legitimate independence would deter the creation of many abusive compensation packages. The threat of actual judicial review of coinpensation issues should encourage coinpensation committees and boards to examine pay packages more thoroughly, comparing them against the yardstick of genuine long-term ownership.

\section{CONCLUSION}

Grabbing someone by his W-2 does not offer the best solution for the problems presented by the coinpensation of executives. Unfortunately, numerous business pundits and regulatory entities have focused on the symptoin of high societal pay levels and adopted the incentive pay systern as a model of corporate governance. Their advocacy neglects the ideal of ownership and encourages coinpanies to compensate executives all the way to detrimental performance that may culminate in financial disasters similar to those of Kidder Peabody or Barings. Ownership interpreted through the mechanism of the courts offers a more sound approach. Society must reach beyond performance in attempts to own the heart and mind of the corporate executive. In short, let go of his W-2, hand him a proprietor's Schedule C, and allow the courts to do the rest. 